\title{
Article \\ Al-Mn Intermetallics in High Pressure Die Cast AZ91 and Direct Chill Cast AZ80
}

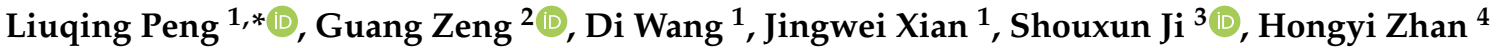 \\ and Christopher M. Gourlay ${ }^{1, *(\mathbb{D})}$
}

1 Department of Materials, Imperial College London, London SW7 2AZ, UK; di.wang19@imperial.ac.uk (D.W.); j.xian@imperial.ac.uk (J.X.)

2 School of Materials Science and Engineering, Central South University, Changsha 410083, China; g.zeng@csu.edu.cn

3 Brunel Centre for Advanced Solidification Technology (BCAST), Brunel University London, Uxbridge UB8 3PH, UK; Shouxun.Ji@brunel.ac.uk

4 China Science Lab, General Motors Global Research \& Development, 56 Jinwan Road, Shanghai 201206, China; henry.zhan@gm.com

* Correspondence: liuqing.peng15@imperial.ac.uk (L.P.); c.gourlay@imperial.ac.uk (C.M.G.)

check for updates

Citation: Peng, L.; Zeng, G.; Wang, D.; Xian, J.; Ji, S.; Zhan, H.; Gourlay, C.M. Al-Mn Intermetallics in High Pressure Die Cast AZ91 and Direct Chill Cast AZ80. Metals 2022, 12, 266. https://doi.org/10.3390/ met12020266

Academic Editor: Noé Cheung

Received: 14 December 2021

Accepted: 27 January 2022

Published: 31 January 2022

Publisher's Note: MDPI stays neutral with regard to jurisdictional claims in published maps and institutional affiliations.

Copyright: (C) 2022 by the authors. Licensee MDPI, Basel, Switzerland. This article is an open access article distributed under the terms and conditions of the Creative Commons Attribution (CC BY) license (https:// creativecommons.org/licenses/by/ $4.0 /)$.

\begin{abstract}
Manganese-bearing intermetallic compounds (IMCs) are important for ensuring adequate corrosion performance of magnesium-aluminium alloys and can be deleterious to mechanical performance if they are large and/or form clusters. Here, we explore the formation of Al-Mn IMCs in $\mathrm{Mg}-9 \mathrm{Al}-0.7 \mathrm{Zn}-0.2 \mathrm{Mn}$ produced by two industrial casting processes, high-pressure die casting

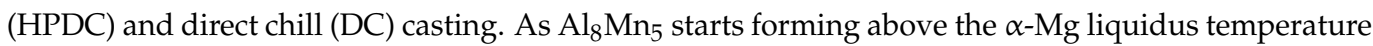
in this alloy, we consider its formation during melt handling as well as during casting and heat treatment. In HPDC, we focus on sludge formation in the holding pot, partial solidification of IMCs in the shot chamber, and Al-Mn IMC solidification in the die cavity. In DC casting, we focus on interactions between Al-Mn IMCs and oxide films in the launder system, Al-Mn IMC solidification in the billet, and the partial transformation of $\mathrm{Al}_{8} \mathrm{Mn}_{5}$ into $\mathrm{Al}_{11} \mathrm{Mn}_{4}$ during solution heat treatment. The results show that minimising pre-solidification in the shot sleeve of HPDC and controlling pouring and filtration in DC casting are important for ensuring small Al-Mn intermetallic particles in these casting processes.
\end{abstract}

Keywords: Mg-Al-Zn alloys; solidification; intermetallics; HPDC; DC casting; microstructure; electron backscatter diffraction (EBSD)

\section{Introduction}

AZ series alloys are the most widely used $\mathrm{Mg}$ alloys in the automotive industry for lightweight requirements, while providing adequate strength at an acceptable cost [1-4]. The $\mathrm{Al}$ and $\mathrm{Zn}$ contents normally range from $\sim 3$ to $9 \mathrm{wt} . \% \mathrm{Al}$ and $\sim 0$ to $2 \mathrm{wt} . \% \mathrm{Zn}$ for different levels of strength and processability. For high strength AZ alloys, the mostly commonly used composition is approximately Mg-9Al-0.7Zn-0.2Mn (wt.\%), with low levels of transition metal impurities. The standard name of this alloy depends on the processing route: AZ91D when used for high pressure die casting (HPDC) [5], AZ91E when used for sand casting and investment casting [6,7], and AZ80A when used for forgings [8]. As shown in Figure 1, the limits of the AZ91 and AZ80 composition ranges overlap over much of their range.

Mg-9Al-0.7Zn-0.2Mn produced by these different processing routes are used in different applications. HPDC AZ91D is used for thin-walled one-piece automotive parts such as the transmission case, 4-wheel drive transfer case, valve cover, oil pan, steering box, and clutch pedal [2]. AZ80A produced by direct chill (DC) casting and forging is used for wrought wheels in motor racing and high performance cars [9], as well as in structural helicopter components [10]. 
(a)

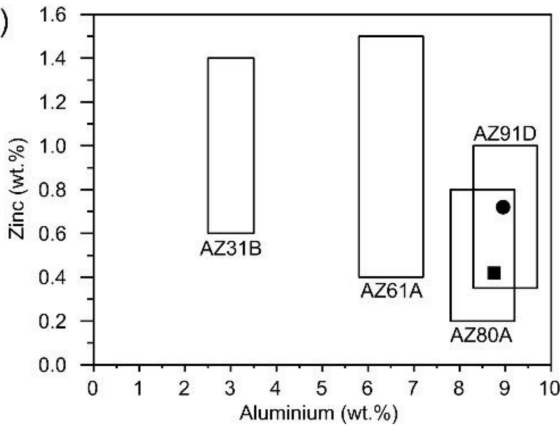

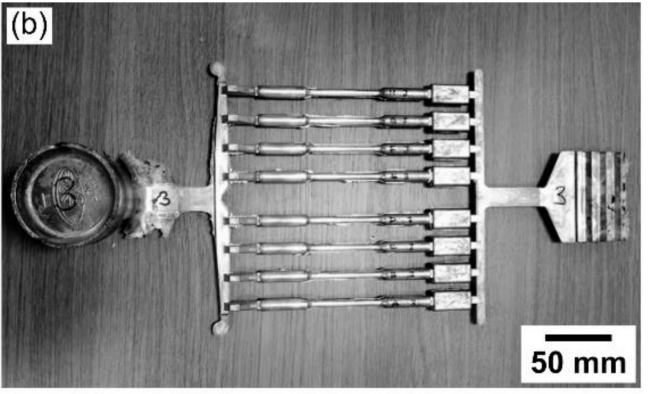

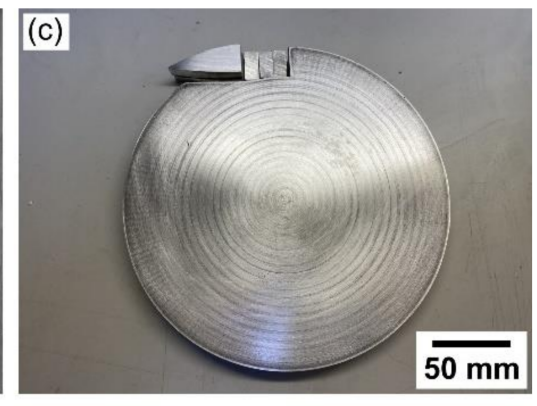

Figure 1. (a) Composition range of $\mathrm{Al}$ and $\mathrm{Zn}$ in selected high-purity $\mathrm{AZ}$-series alloys-AZ31B, AZ61A, AZ80A, and AZ91D from ASTM standards [5,8,11]. Black circle and square mark the composition of (b) the HPDC AZ91D and (c) the DC-cast AZ80A used in this study, respectively.

AZ alloys also contain a small but important manganese addition. If manganese is not added, the impurity iron reacts with aluminium solute in the liquid to form Al-Fe intermetallic compounds (IMCs), which act as damaging micro-cathodes in the anodic $\alpha-\mathrm{Mg}$, resulting in unacceptable corrosion rates [12-16]. The addition of $\sim 0.15-0.50 \mathrm{wt} . \%$ Mn ties up low levels of impurity Fe in Al-Mn IMCs with Fe partially occupying Mn lattice sites. These Al-Mn IMCs are closely correlated to the micro-galvanic corrosion in the $\alpha-\mathrm{Mg}$ matrix [13,17-19], and usually act as less-damaging micro-cathodes in $\alpha-\mathrm{Mg}[12,13]$.

Al-Mn IMCs formed during casting normally have a minor effect on the mechanical properties in the as-cast condition (e.g., [20]) as their volume fraction is small ( 0.25 wt.\%), and they are evenly distribution in the microstructure. However, past work [21] has shown that $\mathrm{Al}_{8} \mathrm{Mn}_{5}$ particles can cluster on entrained oxide and form large defects that can significantly reduce the yield strength and embrittle the alloy.

In recent years, there have been extensive studies [22-34] that have advanced the understanding of the fundamentals of Al-Mn IMC behaviour in magnesium alloys based on controlled laboratory experiments. However, it is unclear how these findings relate to Al-Mn IMC formation in industrial casting processes. The aim of this study is to link from experiments on the fundamentals of Al-Mn IMCs formation during solidification and solution heat treatment to Al-Mn IMCs in castings produced by high-pressure die casting (HPDC) and direct chill (DC) casting. The paper is split into three parts. We first overview key results from laboratory studies on Al-Mn IMC formation during solidification and solution heat treatment of Mg-9Al-0.7Zn-0.2Mn. We then explore how this compares with Al-Mn IMCs in HPDC AZ91D in the as-cast condition, as HPDC parts are often not heat-treated. Finally, we explore DC cast AZ80A in the solutionised condition as this is the usual starting material for forging.

The mechanical behaviour of the HPDC and DC cast samples was not studied here. Past work has shown that, in the as-cast condition, HPDC parts usually have higher yield stress and lower elongation than equivalent DC cast parts [2] owing to HPDCs' finer microstructural length scale, but higher amount of casting defects. The yield strength of DC cast ingot can be substantially improved by forging with or without a subsequent precipitation heat treatment [35]. The role of $\mathrm{Al}_{8} \mathrm{Mn}_{5}$ particles on deformation and fracture in AZ91/AZ80 is discussed in [31,33].

\section{Materials and Methods}

Al-Mn IMCs were studied in three types of casting: (i) samples from an AZ91 laboratory study, (ii) an HPDC AZ91D casting (Figure 1b) and sludge from an HPDC holding pot, and (iii) a DC-cast billet of AZ80A (Figure 1c).

The laboratory solidification study started with a batch of high purity AZ91 ingot with the composition in Table 1 . AZ91 cylinders of $\sim 2 \mathrm{~g}$ were cut from the ingot. Flat-bottomed cylindrical $\mathrm{Al}_{2} \mathrm{O}_{3}$ crucibles with dimensions of inner diameter $9 \mathrm{~mm}$ and height $30 \mathrm{~mm}$ were adopted to avoid the effect of Fe from conventional steel crucibles. The AZ91 cylinders 
in the $\mathrm{Al}_{2} \mathrm{O}_{3}$ crucibles were melted and held at $700{ }^{\circ} \mathrm{C}$ for $120 \mathrm{~min}$, within sealed quartz tubes backfilled with Ar. After the desired holding time, the samples were solidified in one of two ways. In method 1, the hot quartz tube was placed in the vertical cylindrical hole of a steel mould at room temperature. The cooling rate was measured as $\sim 1 \mathrm{~K} / \mathrm{s}$. In method 2, the furnace was turned off and the lid was removed, leading to a slow cooling rate of $\sim 0.1 \mathrm{~K} / \mathrm{s}$. In method 2 , the cooling rate was abruptly increased at $430{ }^{\circ} \mathrm{C}$ by removing the quartz tube to the hole in a steel mould at room temperature to minimise any solid-state transformations after solidification.

Table 1. Chemical composition of the AZ91 and AZ80 used in this study, measured by X-ray fluorescence (XRF) spectrometry.

\begin{tabular}{cccccccccc}
\hline Alloy & \multicolumn{9}{c}{ Composition (wt. \%) } \\
\hline & Mg & Al & Zn & Mn & Cu & Si & Ni & Fe \\
\hline AZ91 & Bal. & 8.95 & 0.72 & 0.19 & 0.001 & 0.039 & $<0.001$ & $<0.001$ \\
\hline AZ80 & Bal. & 8.75 & 0.42 & 0.21 & $<0.001$ & 0.01 & $<0.001$ & 0.004 \\
\hline
\end{tabular}

To study the solid-state transformation of Al-Mn IMCs during solution heat treatment, specimens were cut from similar locations of the AZ91 ingot into $20 \mathrm{~mm} \times 20 \mathrm{~mm} \times 20 \mathrm{~mm}$ cubes. These specimens were held in a forced-air convection oven at $410 \pm 4{ }^{\circ} \mathrm{C}$ for different times $(0,0.5,1,2,3,5,6,21$, and 90 days) and then cooled in water. For heat treatments longer than 6 days, samples were sealed in quartz tubes backfilled with Ar. Samples for other shorter heat treatments were coated by boron nitride and directly placed in the oven.

To study HPDC samples of AZ91D, ingots were used from the same batch of AZ91 as in the laboratory solidification study with the composition in Table 1 . The alloy was heated in a mild steel crucible to $675^{\circ} \mathrm{C}\left(\sim 75^{\circ} \mathrm{C}\right.$ superheat). HPDC was performed using a Frech DAK 450-54 cold chamber HPDC machine with a die preheated to $150{ }^{\circ} \mathrm{C}$ and further heated by at least six pre-shots. The shot chamber fill fraction was $\sim 0.5$ and the set parameters were slow shot phase $0.3 \mathrm{~m} \mathrm{~s}^{-1}$, fast shot phase $4 \mathrm{~m} \mathrm{~s}^{-1}$, and intensification pressure $36 \mathrm{MPa}$. The die produced the tensile bars casting in Figure 1b. Additionally, a sample of sludge was shovelled from the bottom of an industrial HPDC holding pot of AZ91 to produce a sample to study the settled IMCs.

To study a DC cast billet of AZ80A, a $20 \mathrm{~mm}$ thick slice from a $210 \mathrm{~mm}$ diameter DC cast forging billet was provided by Magnesium Elektron. This billet has been solutionised after casting and had the composition in Table 1. Note that both alloys studied here have compositions that simultaneously conform with the requirements of AZ91D and AZ80A, as shown in Figure 1a.

The microstructure of Al-Mn IMC particles was examined by analytical scanning electron microscopy (SEM). Cross sections were prepared via grinding with ethanol with \#2000 and \#4000 grit SiC paper for 1 and $5 \mathrm{~min}$, respectively, followed by polishing with $20 \%$ OPS in ethanol for $12 \mathrm{~min}$, and cleaned in ultrasonic bath in ethanol. SEM investigation was performed using a Zeiss Sigma-300. To reveal the 3D morphology of IMC particles, the samples were etched in 10\% nitric acid in ethanol for 5-10 min to selectively dissolve the $\alpha$-Mg. HPDC samples were etched in a solution of $200 \mathrm{~mL}$ of ethylene glycol, $68 \mathrm{~mL}$ of distilled water, $4 \mathrm{~mL}$ nitric acid, and $80 \mathrm{~mL}$ acetic acid. Secondary electron (SE) and backscattered electron (BSE) images were taken with an accelerating voltage of $10 \mathrm{kV}$ and a working distance of $10 \mathrm{~mm}$. Energy-dispersive X-ray spectroscopy (EDS) was performed using an accelerating voltage of $10 \mathrm{kV}$, a $60 \mu \mathrm{m}$ aperture, and a working distance of $5 \mathrm{~mm}$ with an OXFORD X-Max detector. Electron backscattered diffraction (EBSD) was carried out using $20 \mathrm{kV}$ accelerating voltage and $15 \mathrm{~mm}$ working distance, with a $120 \mu \mathrm{m}$ aperture, the sample tilted at $70^{\circ}$, and a Bruker e-FlashHR EBSD detector. For indexing of EBSD patterns, the phases that were considered in the Bruker Quantax Esprit 2.1 and Bruker DynamicS software are listed in Table 2 along with their crystallographic details and references to the original crystallographic studies. 
Table 2. Crystal structures and lattice parameters used for analysing and indexing EBSD patterns.

The structures from [36-40] were assumed in this work.

\begin{tabular}{|c|c|c|c|c|c|c|c|c|c|c|}
\hline \multirow{2}{*}{ Phase } & \multirow{2}{*}{ Symbol } & \multirow{2}{*}{ Space Group } & \multirow{2}{*}{ Pearson Symbol } & \multicolumn{6}{|c|}{ Lattice Parameters } & \multirow{2}{*}{ Ref. } \\
\hline & & & & a [Å] & b [Å] & c [Å] & $\alpha\left[^{\circ}\right]$ & $\beta\left[^{\circ}\right]$ & $\gamma\left[^{\circ}\right]$ & \\
\hline $\mathrm{Mg}$ & $\alpha$ & $\mathrm{P}_{3} / \mathrm{mmc}$ & $h P 2$ & 3.209 & 3.209 & 5.211 & 90.0 & 90.0 & 120.0 & [36] \\
\hline $\mathrm{Al}_{8} \mathrm{Mn}_{5}$ & $\gamma_{2}$ & $\mathrm{R} 3 m \mathrm{H}$ & $h R 26$ & 12.674 & 12.674 & 7.946 & 90.0 & 90.0 & 120.0 & [37] \\
\hline $\mathrm{Al}_{11} \mathrm{Mn}_{4}$ & $v$ & $P \overline{1}$ & $a P 15$ & 5.095 & 8.879 & 5.051 & 89.4 & 100.0 & 105.0 & [38] \\
\hline $\mathrm{Al}_{0.89} \mathrm{Mn}_{1.11}$ & $\tau$ & $\mathrm{P} 4 / \mathrm{mmm}$ & $t P 2$ & 2.770 & 2.770 & 3.540 & 90.0 & 90.0 & 90.0 & [39] \\
\hline $\mathrm{Mg}_{17} \mathrm{Al}_{12}$ & $\beta$ & $I \overline{4} 3 m$ & cI58 & 10.544 & 10.544 & 10.544 & 90.0 & 90.0 & 90.0 & [40] \\
\hline
\end{tabular}

To further understand Al-Mn IMCs in HPDC samples, focused ion beam (FIB) tomography was conducted. A Zeiss AURIGA FEG-SEM equipped with a gallium FIB was used at $30 \mathrm{kV}$ and 52-degree tilt angle. Serial-sectioning FIB milling was conducted with a slice distance of $90 \mathrm{~nm}$ and current of $200 \mathrm{pA}$. Secondary electron images were then aligned, cropped, and processed by an anisotropic diffusion filter in Image (US NIH, USA). 3D reconstruction and crystallographic analysis was performed using Avizo 9.2 (Visualization Science Group, France) and MATLAB 9.2 ${ }^{\mathrm{TM}}$.

The results presented here come from analysis of more than 100 particles from 50 samples in laboratory cast AZ91 samples, various locations in two HPDC bars, and various locations from two DC cast billets.

\section{Results and Discussion}

\subsection{Laboratory Study on Al-Mn IMCs in Solidification and Solution Heat Treatment}

\subsubsection{Thermodynamic Calculations}

Figure 2 overviews the development of Al-Mn IMCs during the solidification of Al8.95Al-0.19Mn (wt.\%) for equilibrium solidification and for the Scheil model, calculated in Thermo-Calc software with the TCMG4.0 database. $\mathrm{Zn}$ was omitted from the calculation to better visualise the liquidus projection and because the solubility of $\mathrm{Zn}$ in the Al-Mn IMCs is very low. Al-Mn IMCs form throughout the solidification sequence. The first IMC, $\mathrm{Al}_{8} \mathrm{Mn}_{5}$, is stable above the $\alpha-\mathrm{Mg}$ liquidus temperature as a primary solidification phase. Below the $\alpha-\mathrm{Mg}$ liquidus, $\mathrm{Al}_{8} \mathrm{Mn}_{5}$ and then $\mathrm{Al}_{11} \mathrm{Mn}_{4}$ are calculated to form with $\alpha-\mathrm{Mg}$ for equilibrium solidification. With the Scheil model, an additional IMC, $\mathrm{Al}_{4} \mathrm{Mn}$, is calculated to form with $\alpha$-Mg before solidification ends with a eutectic reaction involving $\mathrm{Mg}_{17} \mathrm{Al}_{12}$. Although they form in all stages of the solidification sequence, the Al-Mn IMCs make up only $\sim 0.25$ mass $\%$ of the alloy after Scheil solidification, of which $\sim 95 \%$ is $\mathrm{Al}_{8} \mathrm{Mn}_{5}$.

(a)

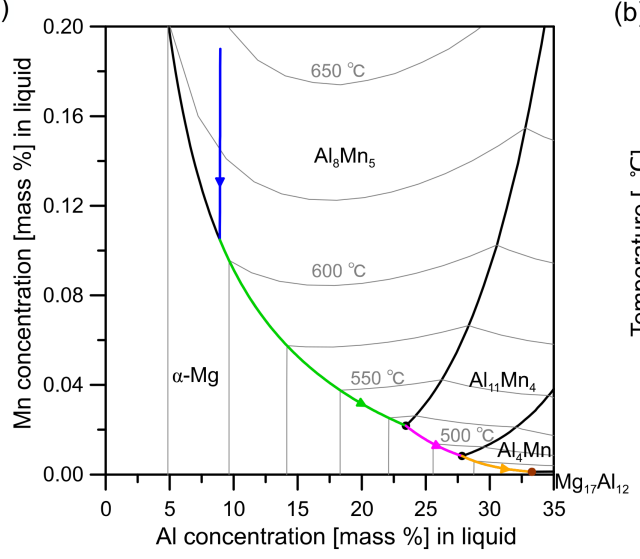

(b)

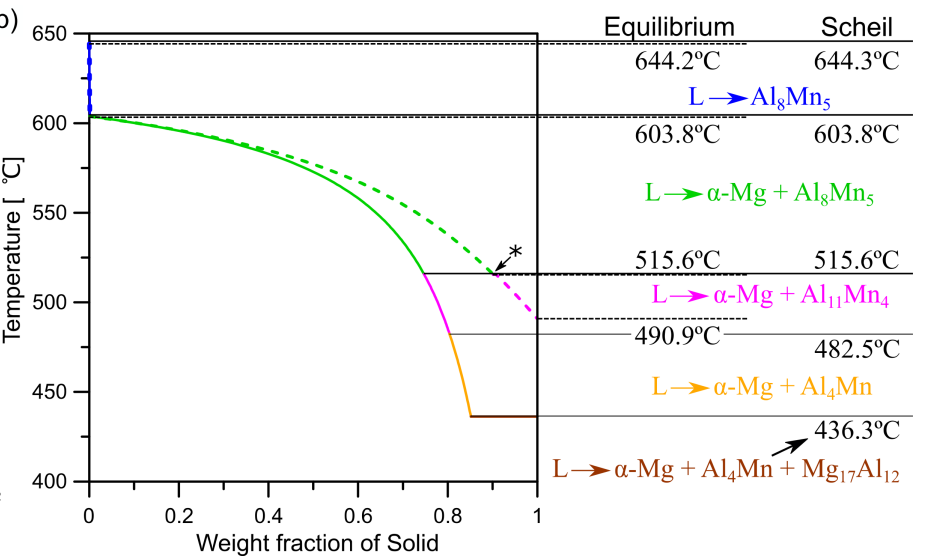

Figure 2. (a) Mg-rich corner of the Mg-Al-Mn liquidus projection calculated in Thermo-Calc software with the TCMG4.0 database. Coloured lines show the change in liquid composition during solidification of Mg-8.95Al-0.19Mn (wt.\%). (b) Development of solid phases during solidification assuming equilibrium and the Scheil model. Colour indicates the solidification reactions in $(\mathbf{a}, \mathbf{b}) .{ }^{\star * \prime}$ indicates the reaction $\mathrm{L}+\mathrm{Al}_{8} \mathrm{Mn}_{5} \rightarrow \alpha-\mathrm{Mg}+\mathrm{Al}_{11} \mathrm{Mn}_{4}$ during equilibrium solidification. 


\subsubsection{Growth of $\mathrm{Al}_{8} \mathrm{Mn}_{5}$ during Solidification}

Past work has confirmed that the majority Al-Mn phase after casting of AZ91 is $\mathrm{Al}_{8} \mathrm{Mn}_{5}[23,24,26]$ and that it usually has the morphology of equiaxed particles or, more rarely, rods [23,24,31]. Zeng et al. identified that the equiaxed particles are cyclic twins [24]. Figure 3 shows a typical $\mathrm{Al}_{8} \mathrm{Mn}_{5}$ equiaxed particle in $\mathrm{Mg}-9 \mathrm{Al}-0.7 \mathrm{Zn}-0.2 \mathrm{Mn}$. From the BSE image and the EBSD phase map in Figure 3a, it can be seen that $\mathrm{Al}_{8} \mathrm{Mn}_{5}$ grew as an equiaxed multifaceted polyhedral particle. According to the IPF-X orientation map, there were four orientations (colours) present in this single-phase particle with three clear linear interfaces.

(a) BSE image

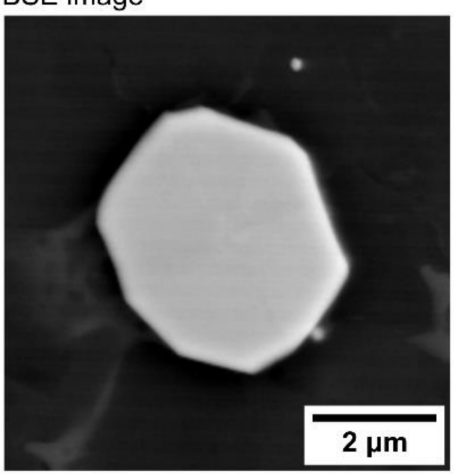

(b)

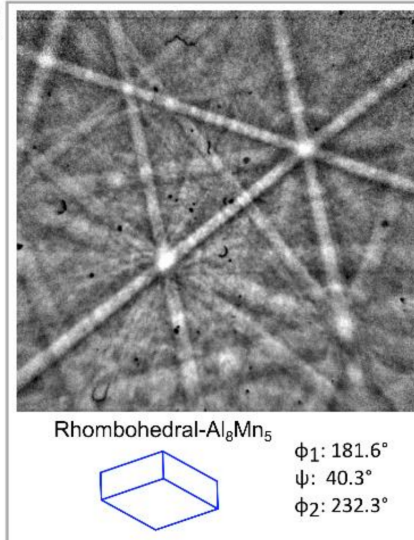

\section{EBSD phase map}

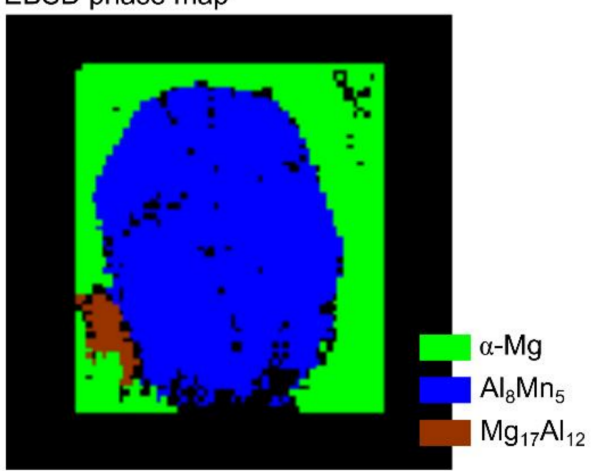

IPF-X $\mathrm{Al}_{8} \mathrm{Mn}_{5}$

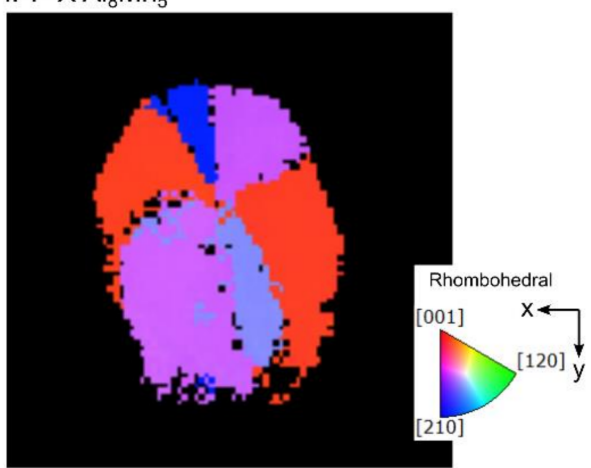

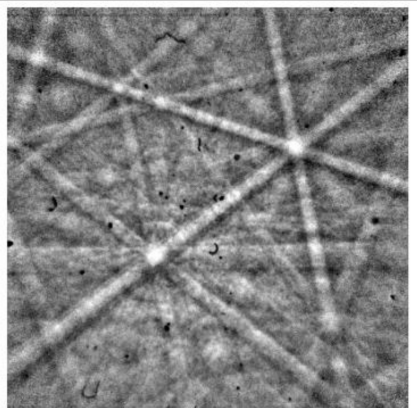

Rhombohedral-Al $\mathrm{Mn}_{5}$

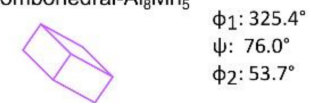

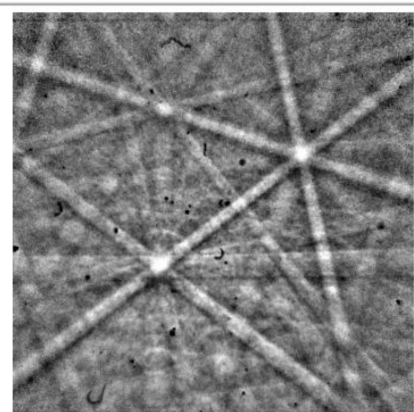

Rhombohedral- $\mathrm{Al}_{8} \mathrm{Mn}_{5}$

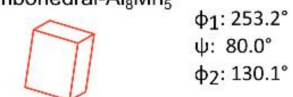

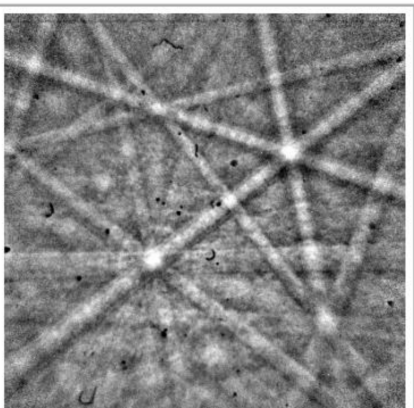

Rhombohedral-Al $\mathrm{Mn}_{5}$ $\phi_{1}: 39.2$ $\psi: 34.6^{\circ}$ $\phi_{2}: 305.5^{\circ}$

(c)

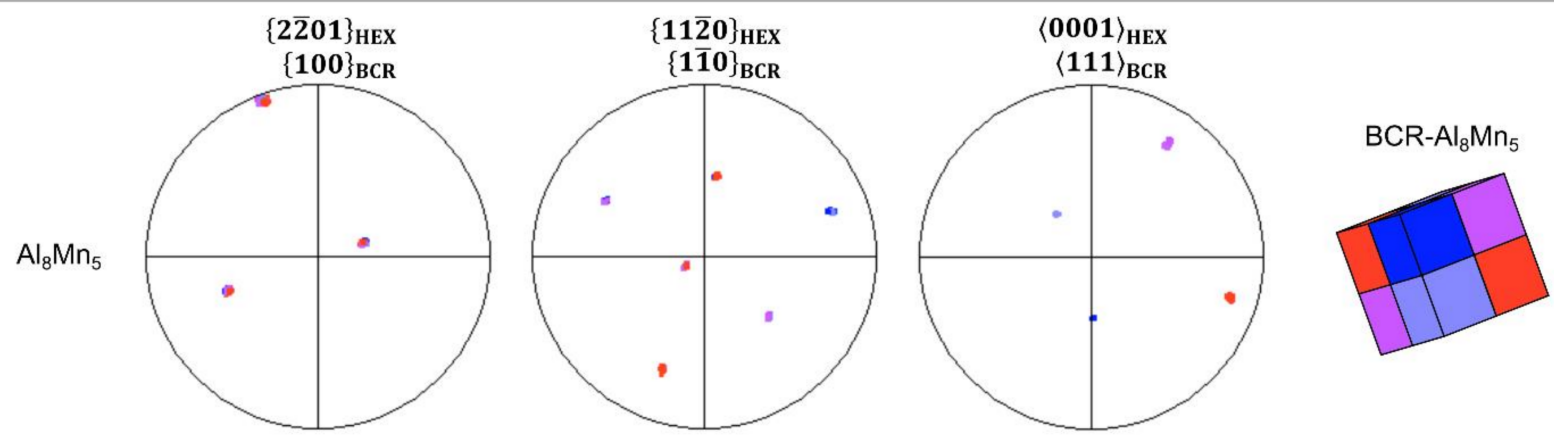

Figure 3. Typical cyclic twinned $\mathrm{Al}_{8} \mathrm{Mn}_{5}$ particle. This example is from the HPDC AZ91D. Similar particles formed in laboratory cast samples. (a) BSE image, EBSD phase map, and IPF-X orientation map. (b,c) Experimental Kikuchi patterns from the four orientations; selected pole figures showing the cyclic twin OR of $\mathrm{Al}_{8} \mathrm{Mn}_{5}$ and the $\{100\}_{B C R}$ interface; unit cell wireframes of four orientations in the $\mathrm{Al}_{8} \mathrm{Mn}_{5}$ cyclic twin from the measured Euler angles.

The experimental Kikuchi patterns of the four orientations are attached beneath in Figure $3 \mathrm{~b}$ with the wire frame unit cells of rhombohedral $\mathrm{Al}_{8} \mathrm{Mn}_{5}$ plotted from the EBSDmeasured Euler angels. These Kikuchi patterns look similar in most of the main bands, but 
differences can be observed in some weaker bands, confirming that there were four distinct orientations in $\mathrm{Al}_{8} \mathrm{Mn}_{5}$ and the EBSD technique can readily distinguish them.

Similar to our previous work [24], those rhombohedral $\mathrm{Al}_{8} \mathrm{Mn}_{5}$ in Figure 3 were cyclic twinned related by $\sim 90^{\circ}$ rotation around three common $\langle 11 \overline{2} 0\rangle_{\text {HEX }}$ axes with $\{2 \overline{2} 01\}_{\text {HEX }}$ twin planes. This cyclic twin can be understood better when considering $\mathrm{Al}_{8} \mathrm{Mn}_{5}$ in the body centred rhombohedral (BCR) setting of $\mathrm{Al}_{8} \mathrm{Mn}_{5}$ with lattice parameters $\mathrm{a}=\mathrm{b}=\mathrm{c}=9.029 \AA$, $\alpha=\beta=\gamma=89.1^{\circ}$ [41], which is pseudo-cubic with $<1^{\circ}$ rhombohedral distortion. In the BCR setting, the cyclic twin planes are $\{100\}_{B C R}$ and the four orientations rotate $\sim 90^{\circ}$ around the $\langle 100\rangle_{B C R}$ axes. This cyclic twin orientation relationship (OR) can be identified in the pole figures in Figure 3c, where all four orientations overlap at each spot in the $\{100\}_{B C R}$ in the pole figure. The plane normal of the $\{100\}_{B C R}$ is also perpendicular to the linear interface in the IPF-X orientation map, indicating that the twin planes are $\{100\}_{B C R}$. The cyclic twin $\mathrm{OR}$ can be visualized in the wire frames attached to the pole figures. Further information on cyclic twinning in $\mathrm{Al}_{8} \mathrm{Mn}_{5}$ is given in [24].

\subsection{3. $\mathrm{Al}_{11} \mathrm{Mn}_{4}$ Nucleation and Growth on $\mathrm{Al}_{8} \mathrm{Mn}_{5}$ during Solidification}

The thermodynamic calculations in Figure 2 indicate that $\mathrm{Al}_{11} \mathrm{Mn}_{4}$ and $\mathrm{Al}_{4} \mathrm{Mn}$ should form during solidification. It was found that $\mathrm{Al}_{11} \mathrm{Mn}_{4}$ formed on $\mathrm{Al}_{8} \mathrm{Mn}_{5}$ when the cooling rate was $\sim 0.1 \mathrm{~K} / \mathrm{s}$ and was usually absent or only present as traces when the cooling rate was $1 \mathrm{~K} / \mathrm{s}$ or higher. For example, the sample in Figure 3 was cooled at $\sim 1 \mathrm{~K} / \mathrm{s}$ and has no $\mathrm{Al}_{11} \mathrm{Mn}_{4}$ on its surface. $\mathrm{Al}_{4} \mathrm{Mn}$ was not detected in this work.

Figure 4 overviews the key features of $\mathrm{Al}_{11} \mathrm{Mn}_{4}$ formation on $\mathrm{Al}_{8} \mathrm{Mn}_{5}$ during solidification at the slow cooling rate of $\sim 0.1 \mathrm{~K} / \mathrm{s}$. Figure 4 a shows the common result that the amount of $\mathrm{Al}_{11} \mathrm{Mn}_{4}$ on $\mathrm{Al}_{8} \mathrm{Mn}_{5}$ varies from particle to particle. The three right-most particles are fully surrounded by $\mathrm{Al}_{11} \mathrm{Mn}_{4}$ plates, but the left-most particle has no discernable $\mathrm{Al}_{11} \mathrm{Mn}_{4}$ on its surface. The development of $\mathrm{Al}_{11} \mathrm{Mn}_{4}$ plates can be understood by examining deep-etched particles with different degrees of $\mathrm{Al}_{11} \mathrm{Mn}_{4}$ growth. Figure $4 \mathrm{~b}, \mathrm{c}$ show $\mathrm{Al}_{11} \mathrm{Mn}_{4}$ growth on the surface of rods of $\mathrm{Al}_{8} \mathrm{Mn}_{5}$. In (b), a thin layer of $\mathrm{Al}_{11} \mathrm{Mn}_{4}$ is present on part of the $\mathrm{Al}_{8} \mathrm{Mn}_{5}$ surface showing the early stages of growth, whereas in (c), well-developed parallel $\mathrm{Al}_{11} \mathrm{Mn}_{4}$ plates are growing around the $\mathrm{Al}_{8} \mathrm{Mn}_{5}$ rod. Figure $4 \mathrm{~d}-\mathrm{f}$ show similar results for $\mathrm{Al}_{11} \mathrm{Mn}_{4}$ growth on $\mathrm{Al}_{8} \mathrm{Mn}_{5}$ equiaxed particles, where an increasing amount of $\mathrm{Al}_{11} \mathrm{Mn}_{4}$ is present from (d) to (f) and the thin lines along the surface of particles in (d) and (e) develop into plates such as those in (f).

The $\mathrm{Al}_{11} \mathrm{Mn}_{4}$ surrounding $\mathrm{Al}_{8} \mathrm{Mn}_{5}$ was usually polycrystalline with multiple reproducible orientation relationships (ORs) to the $\mathrm{Al}_{8} \mathrm{Mn}_{5}$ particle. Figure $4 \mathrm{~g}-\mathrm{h}$ gives an example of a commonly found OR in EBSD studies that can be written $\{11 \overline{2} 0\}_{A l 8 M n 5} \|\{1 \overline{1} 0\}_{A l 11 M n 4}$ and $\langle\overline{1} 101\rangle_{A l 8 M n 5} \|\langle\overline{1} 0 \overline{2}\rangle_{A l 11 M n 4}$. Note that this OR is one of a family of ORs that formed between $\mathrm{Al}_{11} \mathrm{Mn}_{4}$ and $\mathrm{Al}_{8} \mathrm{Mn}_{5}$. Further details are given in [29], which also discusses how these ORs relate to the similarities between these triclinic and rhombohedral crystals. The formation of $\mathrm{Al}_{11} \mathrm{Mn}_{4}$ on the surface of $\mathrm{Al}_{8} \mathrm{Mn}_{5}$ during solidification is consistent with the Scheil solidification reaction sequence in Figure $2 b$, where the quasi-peritectic reaction $\mathrm{L}+\mathrm{Al}_{8} \mathrm{Mn}_{5} \rightarrow \mathrm{Al}_{11} \mathrm{Mn}_{4}+\alpha-\mathrm{Mg}$ starts at the interface between liquid and $\mathrm{Al}_{8} \mathrm{Mn}_{5}$, and then further $\mathrm{Al}_{11} \mathrm{Mn}_{4}$ forms during cooling by $\mathrm{L} \rightarrow \mathrm{Al}_{11} \mathrm{Mn}_{4}+\alpha-\mathrm{Mg}$.

\subsubsection{Transformation of $\mathrm{Al}_{8} \mathrm{Mn}_{5}$ into $\mathrm{Al}_{11} \mathrm{Mn}_{4}$ during Solution Heat Treatment}

For the study of Al-Mn phase transformations during solution heat treatment at $410^{\circ} \mathrm{C}$, starting samples were cut from the as-received AZ91 ingot, which contained $\mathrm{Al}_{8} \mathrm{Mn}_{5}$ and almost no $\mathrm{Al}_{11} \mathrm{Mn}_{4}$ in the as-cast condition. Figure 5a shows typical cross sections of equiaxed Al-Mn particles after different times at $410{ }^{\circ} \mathrm{C}$. The initial $\mathrm{Al}_{8} \mathrm{Mn}_{5}$ particles first developed a shell of $\mathrm{Al}_{11} \mathrm{Mn}_{4}$. The transformation then proceeded by the growth of the $\mathrm{Al}_{11} \mathrm{Mn}_{4}$ shell into the $\mathrm{Al}_{8} \mathrm{Mn}_{5}$ core until all $\mathrm{Al}_{8} \mathrm{Mn}_{5}$ had transformed in $\mathrm{Al}_{11} \mathrm{Mn}_{4}$. It can be seen in Figure $5 \mathrm{a}$ that this transformation resulted in significant cracking of the $\mathrm{Al}_{11} \mathrm{Mn}_{4}$ phase similar to the findings in recent studies $[29,32]$. 

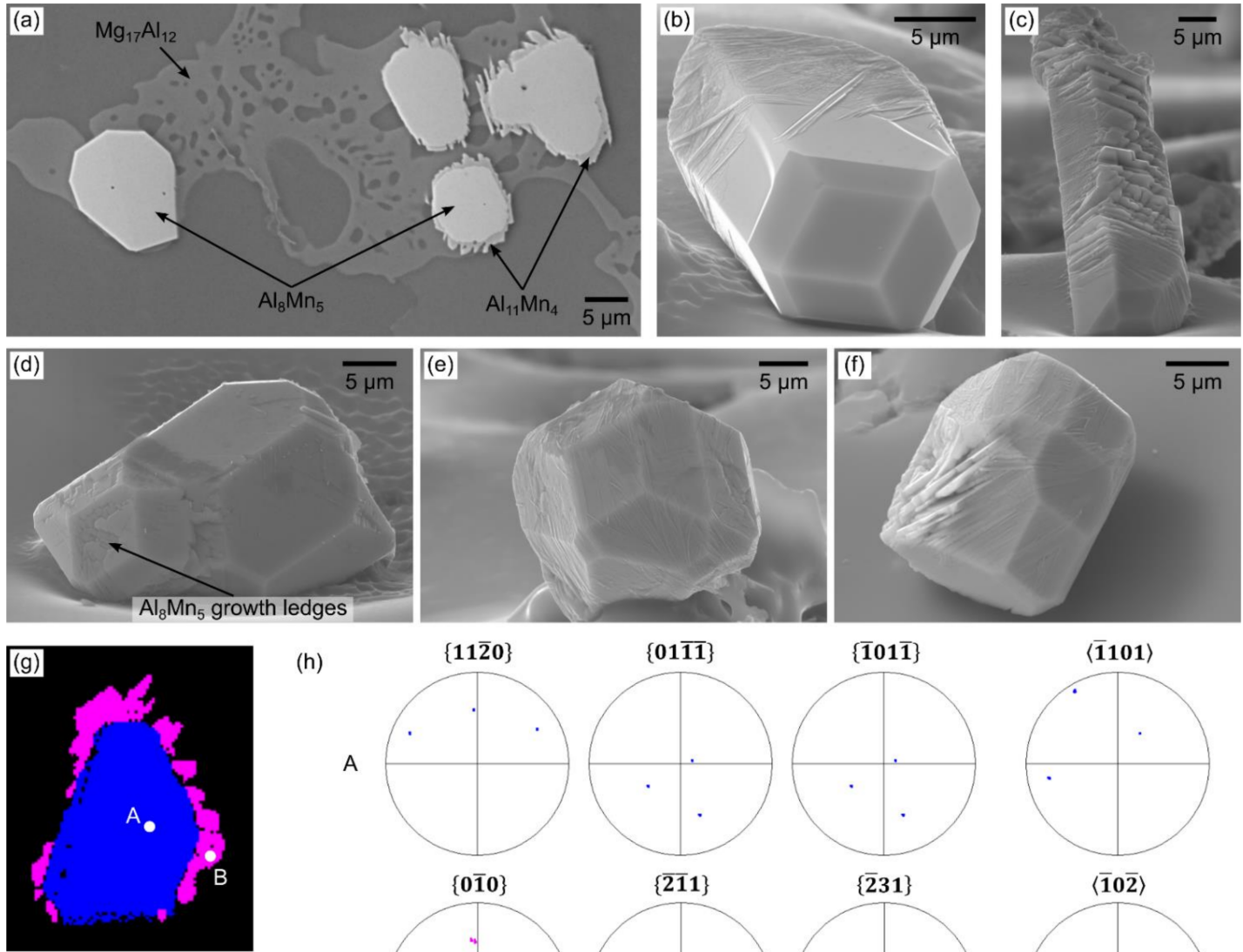

(h)

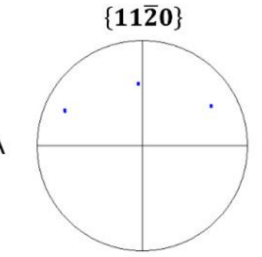

$\{01 \overline{11}\}$

$\{\overline{\mathbf{1 0 1}}\}$

〈1101)

$\mathrm{Al}_{8} \mathrm{Mn}_{5}$

$\mathrm{Al}_{11} \mathrm{Mn}_{4}$
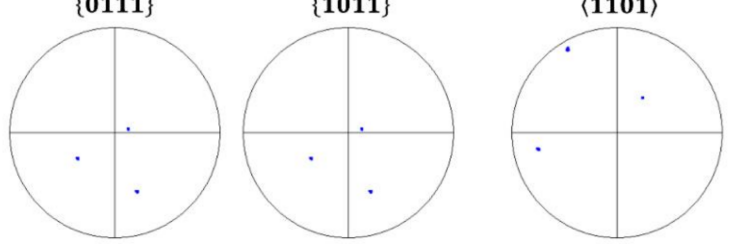

$\{\mathbf{0 1} 0\}$

$\{\overline{211}\}$

$\{\overline{\mathbf{2}} 31\}$

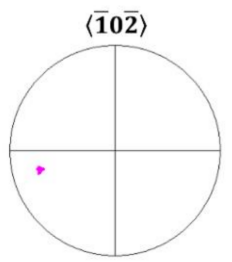

Figure 4. (a) $2 \mathrm{D}$ section showing $\mathrm{Al}_{11} \mathrm{Mn}_{4}$ formed on $\mathrm{Al}_{8} \mathrm{Mn}_{5}$ crystals during solidification with a cooling rate of $\sim 0.1 \mathrm{~K} / \mathrm{s}$. (b,c) $\mathrm{Al}_{11} \mathrm{Mn}_{4}$ growth on $\mathrm{Al}_{8} \mathrm{Mn}_{5}$ rods. (d-f) Different stages of $\mathrm{Al}_{11} \mathrm{Mn}_{4}$ growth on cyclic twinned $\mathrm{Al}_{8} \mathrm{Mn}_{5}$ particles (from traces to fully-covered). N.B. $\mathrm{Al}_{8} \mathrm{Mn}_{5}$ growth ledges are also visible. (g) EBSD phase map of an $\mathrm{Al}_{8} \mathrm{Mn}_{5}$ particle with $\mathrm{Al}_{11} \mathrm{Mn}_{4}$. (h) Pole figures of selected planes and directions showing the OR between $\mathrm{Al}_{8} \mathrm{Mn}_{5}(\mathbf{A})$ and $\mathrm{Al}_{11} \mathrm{Mn}_{4}(\mathbf{B})$.

(a)

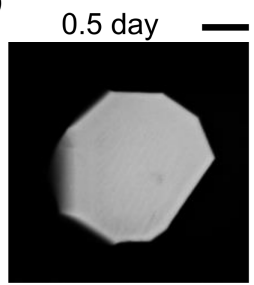

6 day
2 day
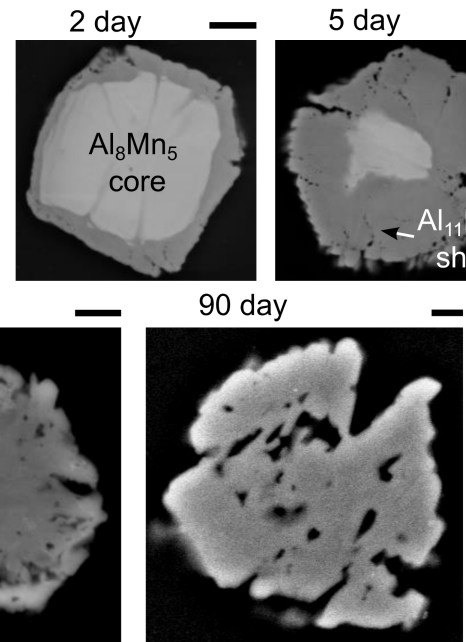

(b)

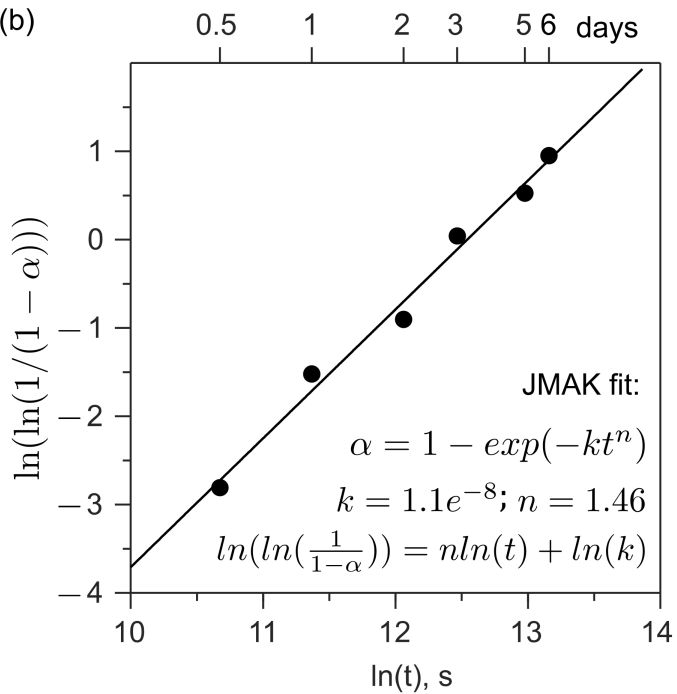

Figure 5. (a) Typical microstructures of solid-state transformation from $\mathrm{Al}_{8} \mathrm{Mn}_{5}$ to $\mathrm{Al}_{11} \mathrm{Mn}_{4}$ up to 90 days. (b) Transformation kinetics fitted with JMAK fit. Note that all scale bars in (a) represent $2 \mu \mathrm{m}$. 
To measure the kinetics of the transformation, the area fractions of $\mathrm{Al}_{11} \mathrm{Mn}_{4}$ and $\mathrm{Al}_{8} \mathrm{Mn}_{5}$ were measured in at least 100 particles for each heat treatment time and converted into a volume fraction transformed using the method in [29]. The transformation kinetics were then analysed using the Johnson-Mehl-Avrami-Kolmogorov (JMAK) equation in Equation (1), where $\alpha$ is the volume fraction of original $\mathrm{Al}_{8} \mathrm{Mn}_{5}$ transformed, and $k$ and $n$ are fitting constants.

$$
\alpha=1-e^{-k t^{n}}
$$

The analysis is plotted in Figure 5b. The data can be well-described by the JMAK equation with an exponent of $\sim 1.5$. This is discussed in terms of the solid-state reaction kinetics in core-shell transformations in [29]. A key feature in Figure 5 is that the transformation of $\mathrm{Al}_{8} \mathrm{Mn}_{5}$ into $\mathrm{Al}_{11} \mathrm{Mn}_{4}$ at $410{ }^{\circ} \mathrm{C}$ took approximately one week to complete, which is slow relative to the time to dissolve the $\mathrm{Mg}_{17} \mathrm{Al}_{12}$ into $\alpha-\mathrm{Mg}$ (approximately one day in these samples).

\subsection{Al-Mn IMCs in HPDC AZ91 \\ 3.2.1. Sludge in Crucible}

Direct observation in synchrotron radiography has confirmed that IMC particles can settle to the bottom of crucibles and form a sludge layer during either heating or solidification of AZ91 [28]. Figure 6 shows the SEM examination of a sludge sample from the bottom of an industrial HPDC holding pot of AZ91. It can be seen in Figure 6a that the settled IMC particles were agglomerated and formed clusters. In Figure 6b, the EBSD inspection identified that those IMC particles were $\mathrm{Al}_{8} \mathrm{Mn}_{5}$ occasionally with small $\mathrm{Al}_{11} \mathrm{Mn}_{4}$ plates on the surface. According to the IPF-Y orientation map, the two isolated $\mathrm{Al}_{8} \mathrm{Mn}_{5}$ particles (top left and middle) contain single or two orientations, whereas the agglomerated particle (bottom right) contains multiple orientations. The middle $\mathrm{Al}_{8} \mathrm{Mn}_{5}$ particle in the IPF-Y map followed the same twin OR as in Figure 3, although only two orientations were present. In the agglomerated particle, each two orientations (yellow and pink, green and orange, and red and blue) had the twin $\mathrm{OR}$, i.e., three twinned $\mathrm{Al}_{8} \mathrm{Mn}_{5}$ were agglomerated. Multiple inspections found that 1-2 orientations were commonly observed in the settled $\mathrm{Al}_{8} \mathrm{Mn}_{5}$, and all had the twinned OR even though the number of twinned orientations per particle was less than four (as was typical of $\mathrm{Al}_{8} \mathrm{Mn}_{5}$ that was not in a sludge layer such as in Figure 3).

(a) BSE image

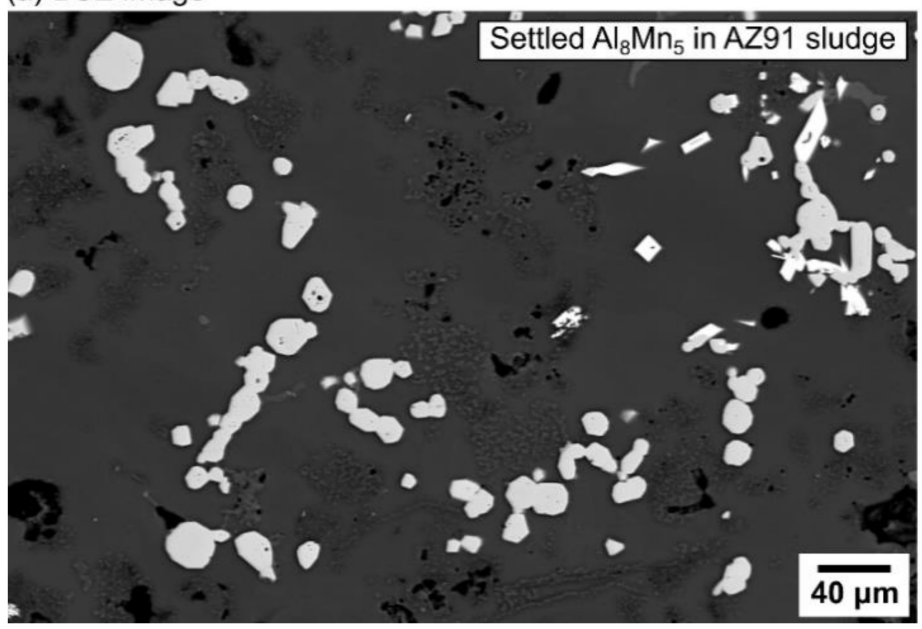

(b) BSE image

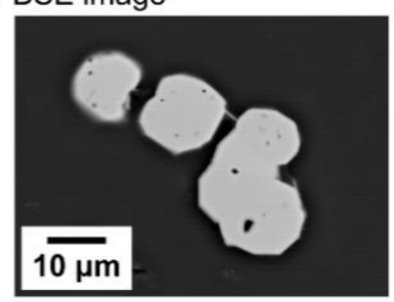

EBSD phase map

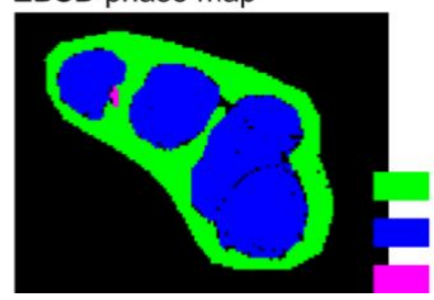

IPF-Y $\mathrm{Al}_{8} \mathrm{Mn}_{5}$

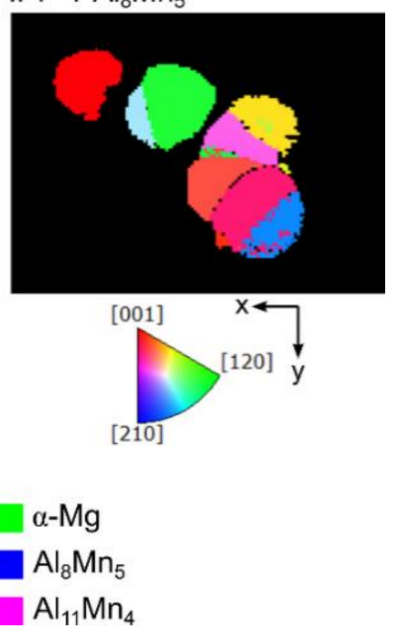

Figure 6. (a) Settled $\mathrm{Al}_{8} \mathrm{Mn}_{5}$ particles in the AZ91 sludge at the bottom of crucible. (b) EBSD phase map and IPF-Y orientation map of settled $\mathrm{Al}_{8} \mathrm{Mn}_{5}$ particles.

\subsubsection{Microstructure Overview}

Figure 7 displays the general microstructure of the HPDC AZ91 from the mould in Figure $1 b$. Figure $7 b, c$ are low magnification optical micrographs of the as-polished and 
deep-etched cross section. The dark bands in Figure $7 \mathrm{~b}$ are porosity defect bands [42-48], and the fine dark networks in Figure $7 \mathrm{c}, \mathrm{d}$ are regions containing a higher fraction of eutectic $\mathrm{Mg}_{17} \mathrm{Al}_{12}$ (positive macrosegregation). The fine eutectic structure can be seen more clearly in the higher magnification SEM images in Figure $7 \mathrm{f}, \mathrm{g}$. The $\alpha$-Mg grains had a complex variety of sizes and morphologies (Figure 7d,e). For example, the EBSD IPF-Y orientation map in Figure 7e contains grains varying in size by more than an order of magnitude.
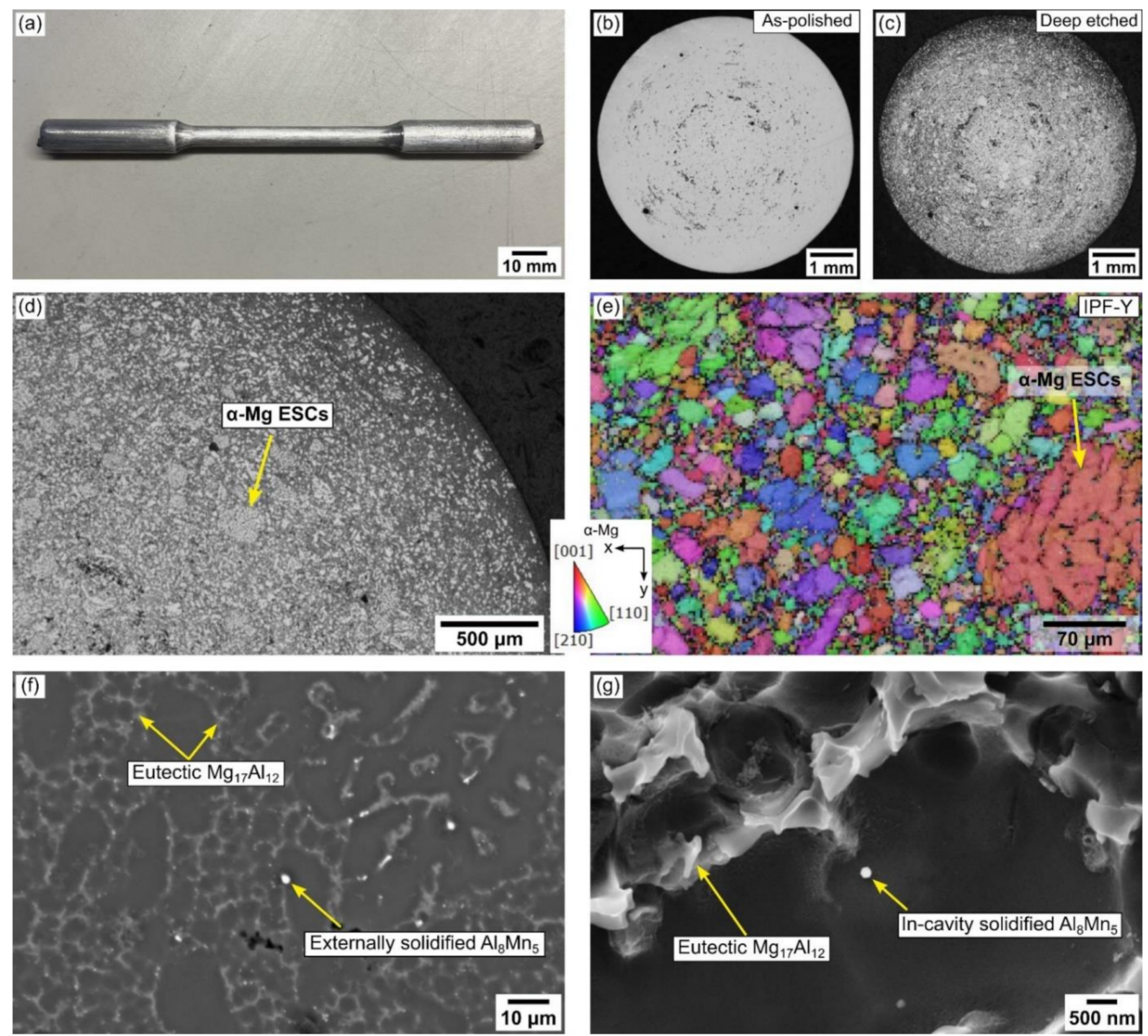

Figure 7. (a) HPDC AZ91 bar from Figure 1b. (b,c) Optical micrographs of the as-polished and deepetched HPDC AZ91 showing the defects and the fine eutectic structure. (d,e) Externally solidified large $\alpha-\mathrm{Mg}$ grain in (c) optical micrograph and (e) EBSD IPF-Y orientation map. (f,g) SE images of the eutectic $\mathrm{Mg}_{17} \mathrm{Al}_{12}$ and $\mathrm{Al}_{8} \mathrm{Mn}_{5}$ particles.

This has previously been attributed to solidification occurring throughout the different stages of HPDC when the cooling and flow conditions vary significantly, as well as to flow transporting $\alpha-\mathrm{Mg}$ grains through the different HPDC stages [47,49-52]. The large $\alpha$-Mg dendrites up to $\sim 150 \mu \mathrm{m}$ in the micrograph and the EBSD IPF-Y orientation map in Figure $7 \mathrm{~d}$,e are externally solidified $\alpha$-Mg crystals (ESCs) that formed in the shot chamber at a low cooling rate before injection in HPDC [49,53-55], where the local temperature dropped below $\sim 600{ }^{\circ} \mathrm{C}$ (Figure 2). In Figure 7f,g, it can be seen that $\mathrm{Al}_{8} \mathrm{Mn}_{5}$ particles in the microstructure also had a wide range of sizes, with the example labelled in (f) being an order of magnitude larger than that labelled in (g). The larger $\mathrm{Al}_{8} \mathrm{Mn}_{5}$ particles in these HPDC 
samples were in the range of $2-5 \mu \mathrm{m}$ in diameter and have even been reported to be $20 \mu \mathrm{m}$ long in other HPDC samples [56]. This size range is comparable with $\mathrm{Al}_{8} \mathrm{Mn}_{5}$ solidified at a low cooling rate [24], so these larger $\mathrm{Al}_{8} \mathrm{Mn}_{5}$ are externally solidified crystals (ESCs) that nucleated and grew in the shot chamber analogous to $\alpha$-Mg ESCs. This interpretation is also consistent with $\mathrm{Al}_{8} \mathrm{Mn}_{5}$ being stable at temperatures above the $\alpha-\mathrm{Mg}$ liquidus (Figure 2). In contrast, the nanoscale $\mathrm{Al}_{8} \mathrm{Mn}_{5}$ were in-cavity solidified particles owing to the high cooling rate in the die cavity during HPDC.

\subsubsection{Al-Mn IMC Formation in HPDC AZ91D}

Figure $8 \mathrm{a}-\mathrm{f}$ shows the microstructure of the in-cavity and externally solidified IMCs in the HPDC AZ91. In the cross-section BSE images, the in-cavity solidified $\mathrm{Al}_{8} \mathrm{Mn}_{5}$ particles were distributed near the eutectic $\mathrm{Mg}_{17} \mathrm{Al}_{12}$ network. They were 200-300 nm particles in size, such as that in Figure $8 \mathrm{~d}$. The externally solidified $\mathrm{Al}_{8} \mathrm{Mn}_{5}$ particles were equiaxed multifaceted polyhedrons around 2-5 $\mu \mathrm{m}$ and evenly distributed in the $\alpha-\mathrm{Mg}$ matrix. In some externally solidified $\mathrm{Al}_{8} \mathrm{Mn}_{5}$, the rod-like $\mathrm{Al}_{8} \mathrm{Mn}_{5}$ grew from the equiaxed polyhedrons, as illustrated in Figure $8 \mathrm{c}-\mathrm{f}$. Figure $8 \mathrm{~g}$ shows FIB tomography reconstructed images of $\mathrm{Al}_{8} \mathrm{Mn}_{5}$ particles in a volume of $\sim 12 \times 12 \times 12 \mu \mathrm{m}^{3}$ at two locations: the defect band and the center of the cross section. Each colour in the reconstructed images represents a unique particle. Figure $8 \mathrm{~h}$ shows the size distribution of these Al-Mn particles in terms of the number of particles in each size bin and the volume occupied by particles in each size bin, for all studied locations combined. The great majority of particles in the plots are less than $1 \mu \mathrm{m}$ in diameter, so these are the size distribution of the in-cavity solidified IMCs and there were no ESCs in the volumes sampled. Note that the particle number histogram appears to be truncated on the small diameter side, indicating that there are likely to also be a significant number of IMCs smaller than $200 \mathrm{~nm}$ that were not detected by this technique.

The externally solidified $\mathrm{Al}_{8} \mathrm{Mn}_{5}$ in Figure $8 \mathrm{~b}$ had the same cyclic twin OR as in Figure 3 and indeed the particle shown in Figure 3 came from the HPDC AZ91 casting. They all agree with previous research in various $\mathrm{Mg}$-Al-based alloys that $\mathrm{Al}_{8} \mathrm{Mn}_{5}$ equiaxed particles are cyclic twins $[24,28,29]$. The in-cavity solidified $\mathrm{Al}_{8} \mathrm{Mn}_{5}$ particles in Figure $8 \mathrm{a}$ were examined by EBSD; however, they were too small to give a clear diffraction pattern in those nanoscale particles. Based on the SEM image (Figure 7f) and the FIB tomography (Figure $8 \mathrm{~h}$ ), it can be seen that the in-cavity solidified $\mathrm{Al}_{8} \mathrm{Mn}_{5} \sim 200-400 \mathrm{~nm}$ were the dominant Al-Mn IMC in the HPDC AZ91, whereas considerably fewer large externally solidified IMCs (Figure 8b,c) were present. Both of them were evenly distributed in the $\alpha-\mathrm{Mg}$ matrix shown in the reconstructed images in Figure $8 \mathrm{~g}$.

$\mathrm{Al}_{11} \mathrm{Mn}_{4}$ was not detected in the HPDC AZ91, probably because the temperature was never low enough in the shot chamber for their formation $\left(\mathrm{Al}_{11} \mathrm{Mn}_{4}\right.$ only becomes stable once $\sim 75 \%$ of the sample is $\alpha-\mathrm{Mg}$ is present according to the calculations in Figure 2 ), and the cooling rate was too high in the die cavity, which suppressed the formation of $\mathrm{Al}_{11} \mathrm{Mn}_{4}$. This is consistent with $\mathrm{Al}_{11} \mathrm{Mn}_{4}$ only forming at a low cooling rate (e.g., $0.1 \mathrm{~K} / \mathrm{s}$ ) in the laboratory study in Figure 4.

In addition to $\mathrm{Al}_{8} \mathrm{Mn}_{5}$, the metastable phase $\tau-\mathrm{Al}_{0.89} \mathrm{Mn}_{1.11}$ was occasionally found in the HPDC AZ91, as shown in Figure 9a. $\tau-\mathrm{Al}_{0.89} \mathrm{Mn}_{1.11}$ formed as a plate. EDS mapping in Figure $9 \mathrm{~b}$ confirmed only $\mathrm{Al}$ and $\mathrm{Mn}$ in this phase. From the EBSD phase map and the IPF-X orientation map (Figure 9c), it can be seen that this single-phase plate contains a single orientation. The wire frame unit cell of $\tau-\mathrm{Al}_{0.89} \mathrm{Mn}_{1.11}$ was plotted on the BSE image using the EBSD-measured Euler angles. To test this phase further, the experimental Kikuchi pattern and a dynamical simulated pattern were compared, as shown in Figure $9 \mathrm{~d}$. Band by band inspection and the high cross-correlation coefficient (ccc) confirm a good agreement with the crystal structure. Lattice planes and directions were indexed on the Kikuchi pattern by OIM software and the selected ones are labelled. 

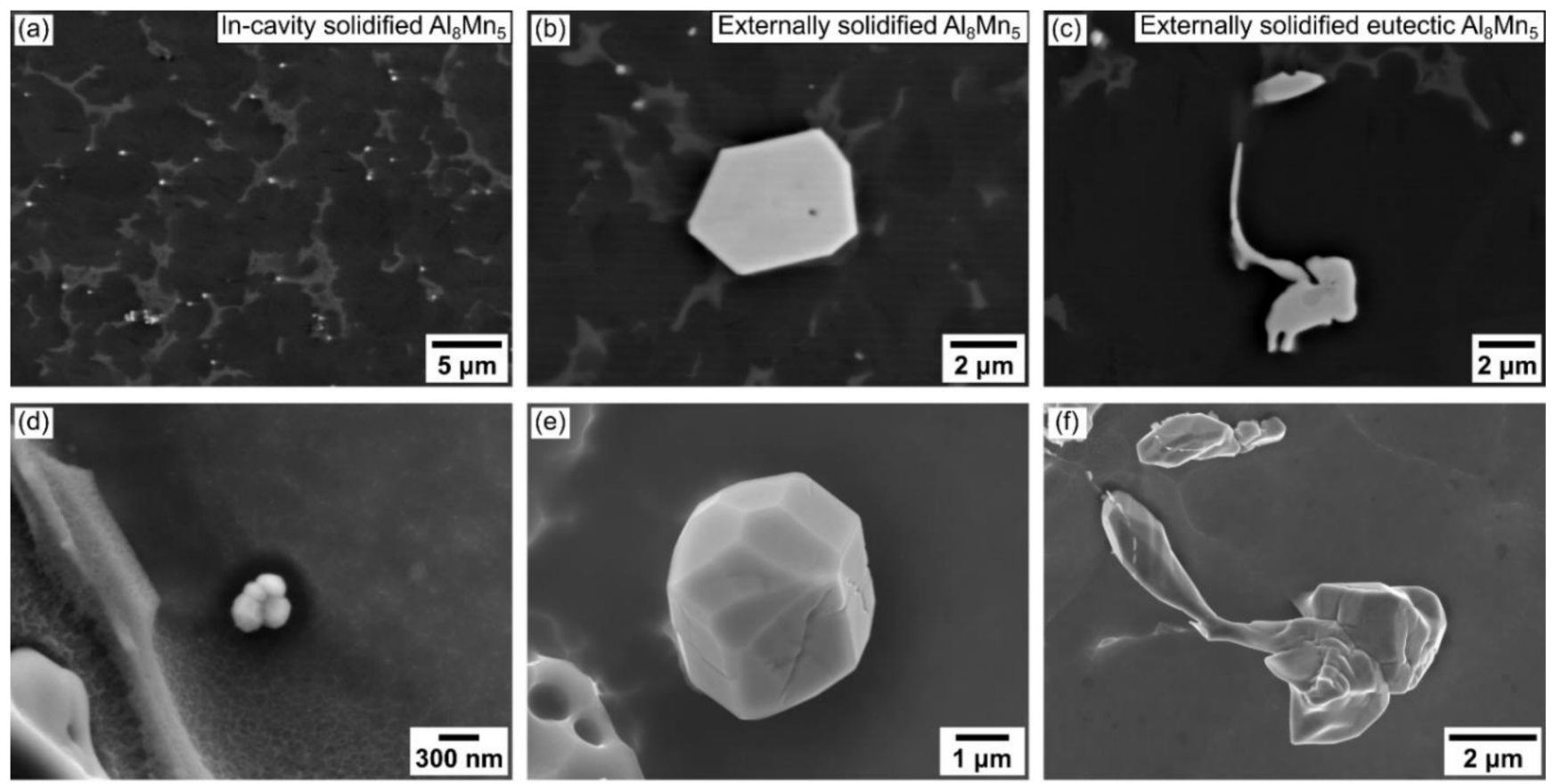

(g)

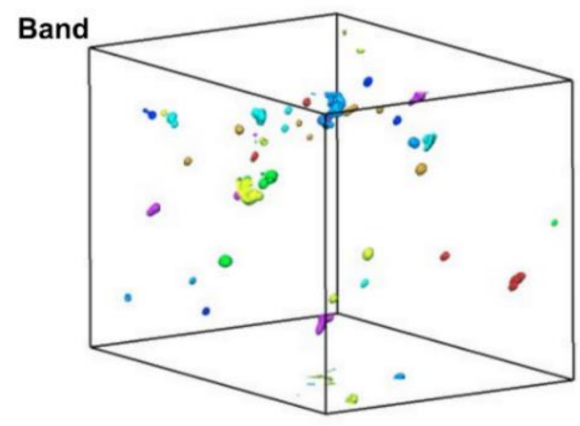

Centre

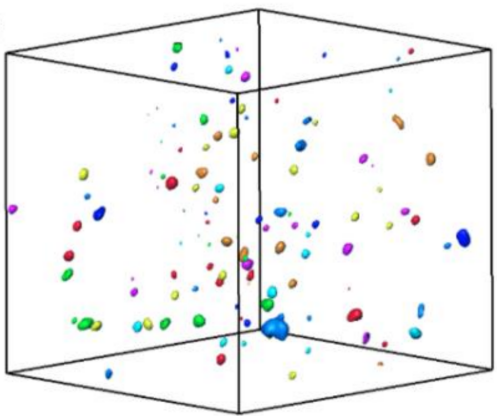

(h)
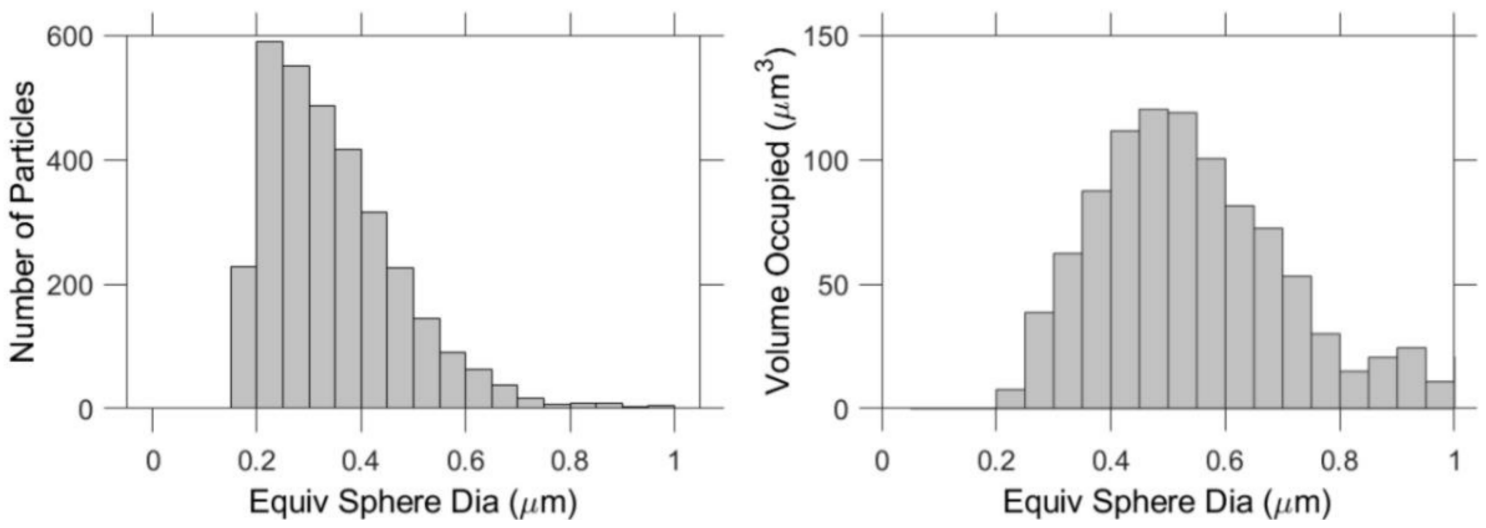

Figure 8. (a-c) Typical microstructure of the Al-Mn IMCs in HPDC-AZ91. (d-f) Deep-etched image showing the 3D morphology of the Al-Mn IMCs. (g,h) FIB tomography for $\mathrm{Al}_{8} \mathrm{Mn}_{5}$ particle size at band and center location in the HPDC sample. (g) FIB tomography rendered images of $\mathrm{Al}_{8} \mathrm{Mn}_{5}$ particles in a volume of $\sim 12 \times 12 \times 12 \mu \mathrm{m}^{3}$ at the defect band and the center of the cross section. Each particle has a unique colour. (h) Number of $\mathrm{Al}_{8} \mathrm{Mn}_{5}$ particles and volume occupation against $\mathrm{Al}_{8} \mathrm{Mn}_{5}$ particle size in all studied volumes. 
(a) BSE image

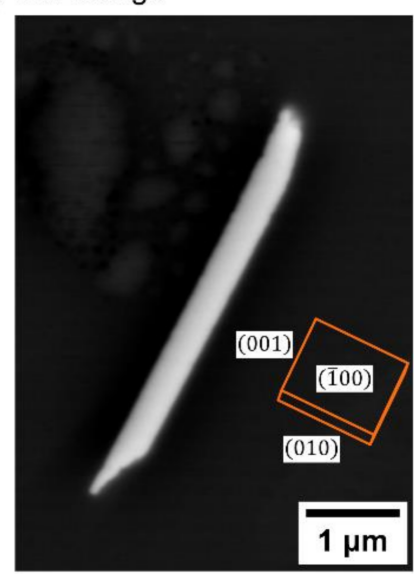

(c) EBSD

phase map

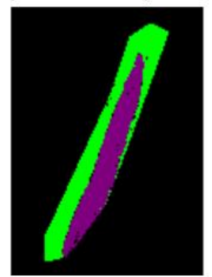

IPF-X

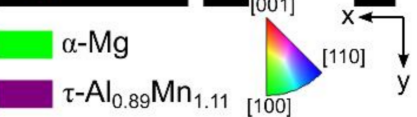

(b) EDS mapping
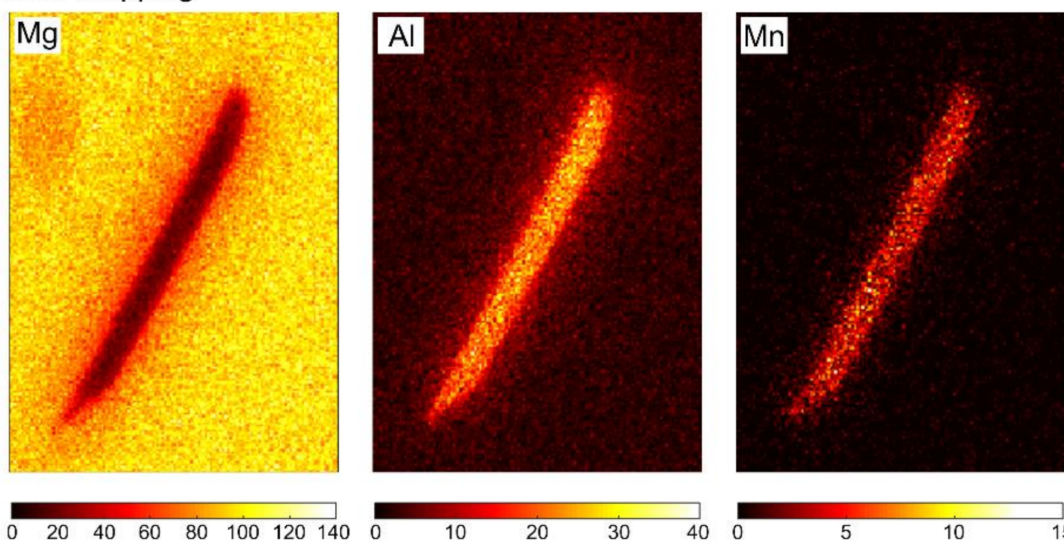

0

Dynamical simulation

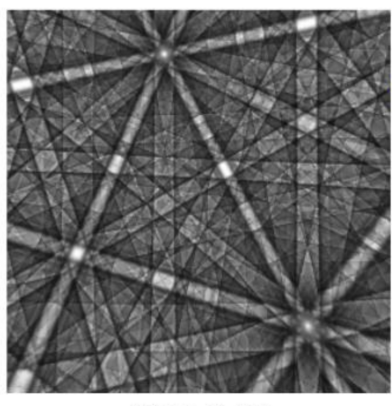

CCC: 0.73 (d) Experimental Kikuchi pattern

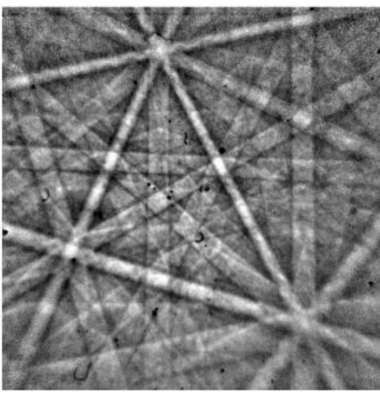

Indexed with OIM

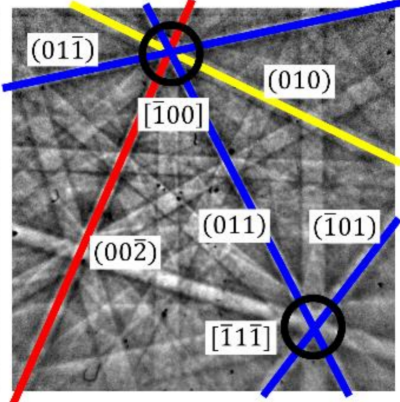

Figure 9. (a) BSE image of the meta-stable phase $\tau-\mathrm{Al}_{0.89} \mathrm{Mn}_{1.11}$ in the HPDC AZ91. (b) EDS mapping, (c) EBSD phase map and IPF-X orientation map of the phase. (d) Experimental Kikuchi pattern and dynamical simulation with cross-correlation coefficient (ccc) and indexed crystal planes and directions.

Past work [25-27] has reported metastable $\tau-\mathrm{Al}_{0.89} \mathrm{Mn}_{1.11}$ in $\mathrm{Mg}-\mathrm{Al}$ alloys with lower $\mathrm{Al}$ content (often in AZ31 [25,27]) and it was never found in our laboratory cast AZ91 cooled at $0.1 \mathrm{~K} / \mathrm{s}$ or $1 \mathrm{~K} / \mathrm{s}$. It seems that the high in-cavity cooling rate of HPDC plays an important role in enabling the formation of the metastable $\tau-\mathrm{Al}_{0.89} \mathrm{Mn}_{1.11}$ in $\mathrm{AZ} 91$. At the same time, we note that almost all Al-Mn particles in the HPDC bars were $\mathrm{Al}_{8} \mathrm{Mn}_{5}$, and that $\tau-\mathrm{Al}_{0.89} \mathrm{Mn}_{1.11}$ was very rare and was only found because it drew our attention with its different shape.

\subsection{Al-Mn IMCs in DC-Cast AZ80A}

\subsubsection{Microstructure of Defect and Defect-Free Region}

Past work has shown that large entrained oxide films with numerous intermetallic particles attached can form as a severe defect in DC cast billets of AZ80 [21] if pouring and filtration are not well controlled. Figure 10a-d shows such defects in the AZ80A billet studied here in low magnification optical microscope images $(a, b)$ and higher magnification BSE images (c,d). The defects involve a combination of entrained oxide, clusters of $\mathrm{Al}_{8} \mathrm{Mn}_{5}$ particles and cracks, and are normally located near the center of the AZ80 billet. In Figure 10a, the cracks initiate from the oxide films as is typical of oxide bifilms [57-61] where one side of the film remains unbonded due to the entrainment process and opens when the liquid pressure decreases due to solidification shrinkage [62]. Figure 10a also shows that large $\mathrm{Al}_{8} \mathrm{Mn}_{5}$ particles are clustered near the entrained oxide. In Figure 10b, note that the IMC particles in the clusters were considerably larger than the typical IMC particles in other parts of the billet. From Figure 10c, d, it can be seen that almost all $\mathrm{Al}_{8} \mathrm{Mn}_{5}$ particles are touching the entrained oxide and are around 2-60 $\mu \mathrm{m}$ in size. 

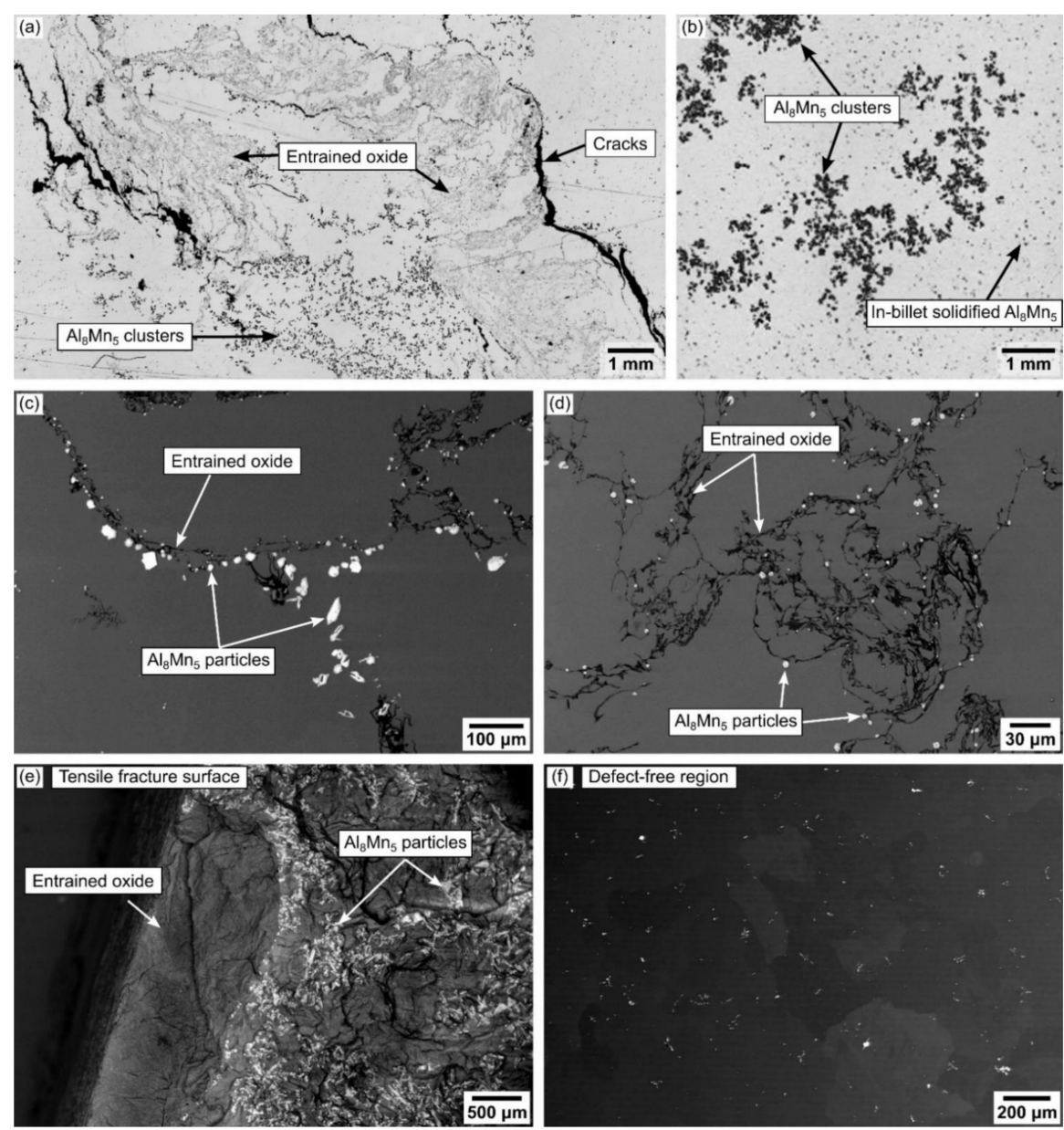

Figure 10. $(\mathbf{a}, \mathbf{b})$ Optical micrographs of a large entrained oxide with clustered Al-Mn IMCs at the center of the DC-cast AZ80 billet. (c,d) BSE images of the defect showing $\mathrm{Al}_{8} \mathrm{Mn}_{5}$ particles clustered on the entrained oxide films. (e) Tensile fracture surface of the defected DC-cast AZ80 sample. (f) BSE image of the defect-free DC-cast AZ80.

The mechanisms by which numerous $\mathrm{Al}_{8} \mathrm{Mn}_{5}$ particles become attached to the entrained oxide have recently been explored in a synchrotron $\mathrm{X}$-ray radiography study that directly observed settling $\mathrm{Al}_{8} \mathrm{Mn}_{5}$ particles interacting with entrained oxides [28]. It was clearly observed that the entrained oxide can act as a filter and trap the $\mathrm{Al}_{8} \mathrm{Mn}_{5}$ particles as they settle. There were also possible sightings of entrained oxide acting as a nucleation site for some $\mathrm{Al}_{8} \mathrm{Mn}_{5}$ particles. The formation of defects in the DC-cast AZ80 in Figure 10a-d is likely to have been by similar mechanisms. The oxide films were likely produced during melt pouring/handling and entrained into the melt. The relatively large size of $\mathrm{Al}_{8} \mathrm{Mn}_{5}$ in Figure $10 \mathrm{~b}, \mathrm{c}$ indicates that the $\mathrm{Al}_{8} \mathrm{Mn}_{5}$ started forming in the launder system where the temperature dropped below $\sim 640{ }^{\circ} \mathrm{C}$ (Figure 2), and were subsequently trapped by the entrained oxide in settling or flow and transported into the DC mould, leading to clusters of large IMCs such as in Figure 10a. In contrast, the $\mathrm{Al}_{8} \mathrm{Mn}_{5}$ particles that nucleated and grew independently in the DC casting mould had a faster cooling rate, giving smaller size IMCs similar to Figure 10c or Figure 10d.

Tensile testing of the AZ80 samples containing such defects gave a fracture surface along the entrained oxide shown in Figure 10e with a large number of clustered $\mathrm{Al}_{8} \mathrm{Mn}_{5}$ particles also visible on the fracture surface. Such combined oxide and $\mathrm{Al}_{8} \mathrm{Mn}_{5}$ cluster defects are identifiable by ultrasonic inspection and so can be sectioned from billets prior to forging. However, this cracking can be avoided by preventing oxide entrainment during DC casting. This requires improved pouring and/or better filters to capture entrained oxides in the launder system. 
Figure 10f overviews the microstructure of a normal region of the AZ80 billet shown in Figure 1c. Compared with Figure 10a-e, it can be seen that the Al-Mn IMCs were evenly distributed in the $\alpha-\mathrm{Mg}$ matrix when entrained oxide was absent. Note that eutectic $\mathrm{Mg}_{17} \mathrm{Al}_{12}$ was absent at the grain boundaries as the AZ80 has been solution heat-treated.

\subsubsection{Microstructure of Al-Mn IMCs in Heat-Treated DC-Cast AZ80A}

Figure 11 shows the typical microstructure of the Al-Mn IMCs in DC-cast AZ80 (Figure 10f) in the solution heat-treated condition. Note that this section refers to normal DC cast billet that does not contain large, entrained oxide and clustered IMCs. Three morphologies of IMC were present: equiaxed polyhedral particles, hexagonal rods, and plates, shown in Figure 11a-c, respectively. In these IMC particles, two shades of grey can be clearly seen in the BSE images that were consistent with $\mathrm{Al}_{8} \mathrm{Mn}_{5}$ surrounded by $\mathrm{Al}_{11} \mathrm{Mn}_{4}$ based on EBSD. Figure 11d-f reveals the 3D shape of the IMCs after $\alpha-\mathrm{Mg}$ was selectively dissolved away. The appearance of $\mathrm{Al}_{11} \mathrm{Mn}_{4}$ is similar to that formed by solidstate transformation in the laboratory study in Figure $5 \mathrm{a}$, indicating that the $\mathrm{Al}_{11} \mathrm{Mn}_{4}$ in DC cast AZ80 mostly formed during solutionizing. Figure $11 \mathrm{~g}-\mathrm{i}$ are high magnification images showing the details of the transformation phase, which consists of numerous $\mathrm{Al}_{11} \mathrm{Mn}_{4}$ plates with nanoscale width covering the surface of $\mathrm{Al}_{8} \mathrm{Mn}_{5}$. Figure $11 \mathrm{j}$ exhibits an EBSD phase map and EDS mapping of the cross section of an IMC particle confirming that $\mathrm{Al}_{8} \mathrm{Mn}_{5}$ phase was partially transformed to $\mathrm{Al}_{11} \mathrm{Mn}_{4}$.
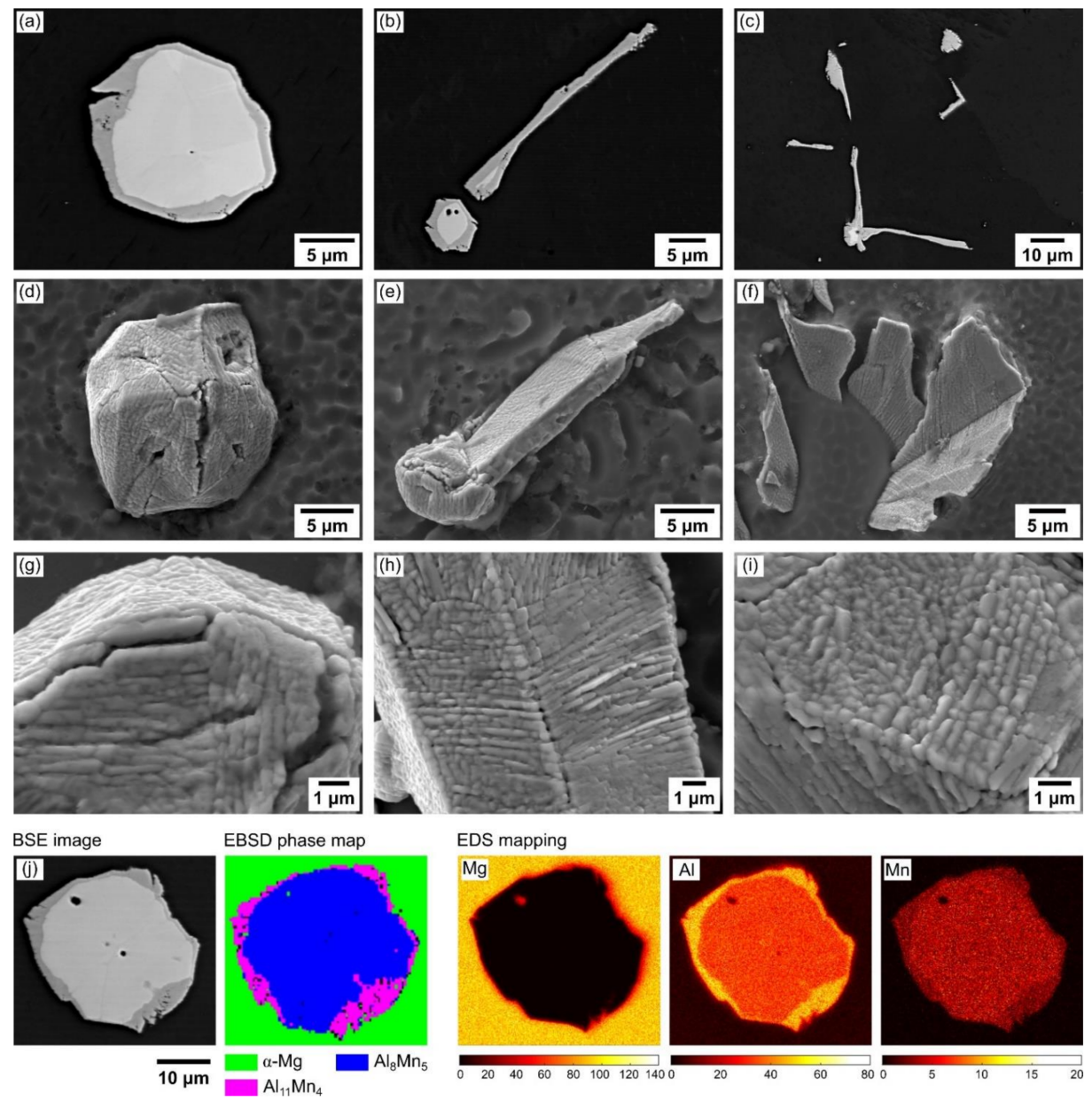

Figure 11. (a-c) Typical microstructure of the Al-Mn IMCs in the heat-treated DC-cast AZ80. (d-f) Deep-etched images showing the 3D morphology of the IMCs. (g-i) Focused images of the solid-state transformed $\mathrm{Al}_{11} \mathrm{Mn}_{4}$ on the surface of the IMCs. (j) Typical polyhedral $\mathrm{Al}_{8} \mathrm{Mn}_{5}$ particle with $\mathrm{Al}_{11} \mathrm{Mn}_{4}$ shell formed during solution treatment, EBSD phase map, and EDS mapping. 
From Figure $11 \mathrm{j}$, it is clear that the solid-state transformation is at a relatively early stage after solution heat treatment. This is consistent with the kinetics of the $\mathrm{Al}_{8} \mathrm{Mn}_{5}$ transformation into $\mathrm{Al}_{11} \mathrm{Mn}_{4}$ in the laboratory study in Figure 5b, where a solutionizing time of 12 or $24 \mathrm{~h}$ gives a calculated fraction transformed of only $0.06-0.16$. Thus, solutionizing after DC casting produces a microstructure of $\alpha-\mathrm{Mg}$ and core-shell particles of $\mathrm{Al}_{8} \mathrm{Mn}_{5}$ surrounded by a layer of $\mathrm{Al}_{11} \mathrm{Mn}_{4}$.

\section{Conclusions}

The microstructure of Al-Mn IMCs has been overviewed in laboratory cast AZ91 with a cooling rate of $\sim 0.1$ and $1 \mathrm{~K} / \mathrm{s} . \mathrm{Al}_{8} \mathrm{Mn}_{5}$ formed as cyclic twinned equiaxed polyhedral particles with multiple facets or, more rarely, as rods and plates. $\mathrm{Al}_{11} \mathrm{Mn}_{4}$ nucleated and grew on the $\mathrm{Al}_{8} \mathrm{Mn}_{5}$ surface as plates late during solidification. $\mathrm{Al}_{11} \mathrm{Mn}_{4}$ was promoted by slow cooling rates with significantly more $\mathrm{Al}_{11} \mathrm{Mn}_{4}$ forming at $0.1 \mathrm{~K} / \mathrm{s}$ that $1 \mathrm{~K} / \mathrm{s}$. During solution heat treatment, $\mathrm{Al}_{8} \mathrm{Mn}_{5}$ transformed into $\mathrm{Al}_{11} \mathrm{Mn}_{4}$ by the growth of a $\mathrm{Al}_{11} \mathrm{Mn}_{4}$ shell into the $\mathrm{Al}_{8} \mathrm{Mn}_{5}$ core until all $\mathrm{Al}_{8} \mathrm{Mn}_{5}$ had transformed.

The HPDC AZ91 sludge from the bottom of the holding pot comprised of settled and agglomerated $\mathrm{Al}_{8} \mathrm{Mn}_{5}$ particles. These were either single crystal or twinned in the same manner as cyclic twins. The $\mathrm{Al}_{8} \mathrm{Mn}_{5}$ in HPDC AZ91D had similar features as in the slow cooled laboratory AZ91 sample, but the particles had a much wider size range owing to the different cooling rates in the shot chamber and die cavity. The in-cavity solidified $\mathrm{Al}_{8} \mathrm{Mn}_{5}$ were $\sim 200-400 \mathrm{~nm}$, whereas the externally solidified $\mathrm{Al}_{8} \mathrm{Mn}_{5}$ were $\sim 2-5 \mu \mathrm{m}$. The in-cavity solidified $\mathrm{Al}_{8} \mathrm{Mn}_{5}$ particles were the majority of Al-Mn IMC in the HPDC AZ91D. The high cooling rate in HPDC suppressed the formation $\mathrm{Al}_{11} \mathrm{Mn}_{4}$, but enabled the formation of a small amount of metastable $\tau-\mathrm{Al}_{0.89} \mathrm{Mn}_{1.11}$.

The section of DC-cast AZ80A billet has been identified to contain a large entrained oxide by prior ultrasonic inspection. It was found that this entrained oxide had large clusters of IMC particles attached. Comparing with recent X-ray imaging experiments, it is likely that the formation mechanism of these clusters is related to the transport in the launder system, where $\mathrm{Al}_{8} \mathrm{Mn}_{5}$ particles are carried in the flow and become trapped by the entrained oxide. It is also possible that some $\mathrm{Al}_{8} \mathrm{Mn}_{5}$ particles nucleated on the oxide. Improved pouring and filtration are required to prevent these entrained oxide and large particles from entering the DC-casting.

In the DC-cast AZ80A, regions of microstructure free from large entrained oxides contained smaller Al-Mn particles that were more evenly distributed. These had a similar size to the laboratory AZ91 samples. Owing to the solution heat treatment, $\mathrm{Al}_{8} \mathrm{Mn}_{5}$ had partially transformed into $\mathrm{Al}_{11} \mathrm{Mn}_{4}$ to produce core-shell particles. The $\mathrm{Al}_{11} \mathrm{Mn}_{4}$ shell consisted of plates with nanoscale width covering the surface of $\mathrm{Al}_{8} \mathrm{Mn}_{5}$. This partial transformation was at a relatively early stage of transformation, which is consistent with the slow kinetics measured in the laboratory study, where it took approximately one week for the reaction to complete.

Author Contributions: Conceptualization, L.P. and C.M.G.; methodology, L.P. and C.M.G.; software, J.X.; validation, L.P., G.Z., D.W., J.X. and C.M.G.; formal analysis, L.P., G.Z., D.W. and J.X.; investigation, L.P., G.Z. and J.X.; resources, G.Z., S.J., H.Z. and C.M.G.; data curation, L.P.; writing-original draft preparation, L.P.; writing—review and editing, C.M.G.; visualization, L.P., D.W., G.Z. and J.X.; supervision, C.G; project administration, C.M.G.; funding acquisition, G.Z. and C.M.G. All authors have read and agreed to the published version of the manuscript.

Funding: This research was funded by Engineering and Physical Sciences Research Council (EPSRC, UK), grant number EP/N007638/1 (the Future LiME Hub), and partly supported by the National Natural Science Foundation of China, grant number 51904352.

Institutional Review Board Statement: Not applicable.

Informed Consent Statement: Not applicable. 
Data Availability Statement: The data presented in this study are available on request from the corresponding author.

Acknowledgments: We gratefully acknowledge the use of characterisation facilities within the Harvey Flower Electron Microscopy Suite, Department of Materials, Imperial College London. We thank Mark Turski of Magnesium Elektron for providing the DC cast forging billet. Financial support from EPSRC (UK) under grant number EP/N007638/1 (the Future LiME Hub) is gratefully acknowledged. This work was partly supported by the National Natural Science Foundation of China (51904352).

Conflicts of Interest: The authors declare no conflict of interest.

\section{References}

1. Blawert, C.; Hort, N.; Kainer, K. Automotive applications of magnesium and its alloys. Trans. Indian Inst. Met. 2004, 57, 397-408.

2. Luo, A.A. Magnesium casting technology for structural applications. J. Magnes. Alloys 2013, 1, 2-22. [CrossRef]

3. Brady, M.P.; Joost, W.J.; Warren, C.D. Insights from a recent meeting: Current status and future directions in magnesium corrosion research. Corrosion 2017, 73, 452-462. [CrossRef]

4. Weiler, J. A review of magnesium die-castings for closure applications. J. Magnes. Alloys 2019, 7, 297-304. [CrossRef]

5. American Society for Testing and Materials, ASTM. B94-18, Standard Specification for Magnesium-Alloy Die Castings; ASTMInternational: West Conshohocken, PA, USA, 2018.

6. American Society for Testing and Materials, ASTM. B80-15, Standard Specification for Magnesium-Alloy Sand Castings; ASTMInternational: West Conshohocken, PA, USA, 2015.

7. American Society for Testing and Materials, ASTM. B403-20, Standard Specification for Magnesium-Alloy Investment Castings; ASTM-International: West Conshohocken, PA, USA, 2020.

8. American Society for Testing and Materials, ASTM. B91-17, Standard Specification for Magnesium-Alloy Forgings; ASTMInternational: West Conshohocken, PA, USA, 2017.

9. Agnew, S.R. Wrought magnesium: A 21st century outlook. JOM 2004, 56, 20-21. [CrossRef]

10. He, H.; Huang, S.; Yi, Y.; Guo, W. Simulation and experimental research on isothermal forging with semi-closed die and multi-stage-change speed of large AZ80 magnesium alloy support beam. J. Mater. Process. Technol. 2017, 246, 198-204. [CrossRef]

11. American Society for Testing and Materials, ASTM. B90-21, Standard Specification for Magnesium-Alloy Sheet and Plate; ASTMInternational: West Conshohocken, PA, USA, 2021.

12. Song, G.L.; Atrens, A. Corrosion mechanisms of magnesium alloys. Adv. Eng. Mater. 1999, 1, 11-33. [CrossRef]

13. Lunder, O.; Nordien, J.; Nisancioglu, K. Corrosion resistance of cast Mg-Al alloys. Corros. Rev. 1997, 15, 439-470. [CrossRef]

14. Hanawalt, J. Corrosion studies of magnesium and its alloys. Trans. AIME 1942, 147, 273-299.

15. Hanawalt, J.D.; Nelson, C.E.; Holdeman, G.E. Removal of iron from magnesiumbase alloys. U.S. Patent 2267862A, 30 December 1941.

16. Esmaily, M.; Svensson, J.; Fajardo, S.; Birbilis, N.; Frankel, G.; Virtanen, S.; Arrabal, R.; Thomas, S.; Johansson, L. Fundamentals and advances in magnesium alloy corrosion. Prog. Mater. Sci. 2017, 89, 92-193. [CrossRef]

17. Lunder, O.; Nisancioglu, K.; Hansen, R.S. Corrosion of Die Cast Magnesium-Aluminum Alloys; 0148-7191; SAE Technical Paper: 930755; SAE International: Warrendale, PA, USA, March 1993.

18. Zeng, R.-C.; Zhang, J.; Huang, W.-J.; Dietzel, W.; Kainer, K.; Blawert, C.; Ke, W. Review of studies on corrosion of magnesium alloys. Trans. Nonferrous Met. Soc. China 2006, 16, s763-s771. [CrossRef]

19. Pawar, S.; Zhou, X.; Thompson, G.; Scamans, G.; Fan, Z. The role of intermetallics on the corrosion initiation of twin roll cast AZ31 Mg alloy. J. Electrochem. Soc. 2015, 162, C442-C448. [CrossRef]

20. Sarvesha, R.; Chalapathi, D.; Yadava, M.; Jain, J.; Singh, S. In-situ studies on deformation and fracture characteristics of AZ91 Mg alloy. Materialia 2021, 18, 101177. [CrossRef]

21. Mackie, D.; Robson, J.; Withers, P.; Turski, M. Characterisation and modelling of defect formation in direct-chill cast AZ80 alloy. Mater. Charact. 2015, 104, 116-123. [CrossRef]

22. Zeng, G.; Nogita, K.; Belyakov, S.; Xian, J.; McDonald, S.; Yang, K.; Yasuda, H.; Gourlay, C. Real-Time Observation of AZ91 Solidification by Synchrotron Radiography. In Magnesium Technology 2017; Springer: Berlin/Heidelberg, Germany, 2017 ; pp. 597-603.

23. Zeng, G.; Xian, J.; Gourlay, C. Growth of Al8Mn5 Intermetallic in AZ91. In Magnesium Technology 2017; Springer: Berlin/Heidelberg, Germany, 2017; pp. 85-92.

24. Zeng, G.; Xian, J.; Gourlay, C. Nucleation and growth crystallography of Al8Mn5 on B2-Al (Mn, Fe) in AZ91 magnesium alloys. Acta Mater. 2018, 153, 364-376. [CrossRef]

25. Han, G.; Ma, G.; Liu, X. Effect of manganese on the microstructure of Mg-3Al alloy. J. Alloy Compd. 2009, 486, 136-141. [CrossRef]

26. Han, G.; Liu, X. Phase control and formation mechanism of $\mathrm{Al}-\mathrm{Mn}(-\mathrm{Fe})$ intermetallic particles in $\mathrm{Mg}-\mathrm{Al}_{-}$-based alloys with $\mathrm{FeCl} 3$ addition or melt superheating. Acta Mater. 2016, 114, 54-66. [CrossRef]

27. Yao, S.; Liu, S.; Zeng, G.; Li, X.; Lei, T.; Li, Y.; Du, Y. Effect of manganese on microstructure and corrosion behavior of the Mg-3Al alloys. Metals 2019, 9, 460. [CrossRef]

28. Peng, L.; Zeng, G.; Su, T.; Yasuda, H.; Nogita, K.; Gourlay, C. $\mathrm{Al}_{8} \mathrm{Mn}_{5}$ Particle Settling and Interactions with Oxide Films in Liquid $\mathrm{AZ}_{91}$ Magnesium Alloys. JOM 2019, 71, 2235-2244. [CrossRef] 
29. Xian, J.; Peng, L.; Zeng, G.; Wang, D.; Gourlay, C. $\mathrm{Al}_{11} \mathrm{Mn}_{4}$ formation on Al8Mn5 during the solidification and heat treatment of AZ-series magnesium alloys. Materialia 2021, 19, 101192. [CrossRef]

30. Chen, T.; Yuan, Y.; Liu, T.; Li, D.; Tang, A.; Chen, X.; Schmid-Fetzer, R.; Pan, F. Effect of Mn Addition on Melt Purification and Fe Tolerance in Mg Alloys. JOM 2021, 73, 892-902. [CrossRef]

31. Sarvesha, R.; Alam, W.; Gokhale, A.; Guruprasad, T.; Bhagavath, S.; Karagadde, S.; Jain, J.; Singh, S. Quantitative assessment of second phase particles characteristics and its role on the deformation response of a Mg-8Al-0.5 Zn alloy. Mater. Sci. Eng. A 2019, 759, 368-379. [CrossRef]

32. Sarvesha, R.; Thirunavukkarasu, G.; Chiu, Y.L.; Jones, I.P.; Jain, J.; Singh, S. A study on the phase transformation of $\gamma 2-\mathrm{Al} 8 \mathrm{Mn} 5$ to LT-Al11Mn4 during solutionizing in AZ91 alloy. J. Alloy Compd. 2021, 873, 159836. [CrossRef]

33. Sarvesha, R.; Bhagyaraj, J.; Bhagavath, S.; Karagadde, S.; Jain, J.; Singh, S. 2D and 3D characteristics of intermetallic particles and their role in fracture response of AZ91 magnesium alloy. Mater. Charact. 2021, 171, 110733. [CrossRef]

34. Peng, L.; Zeng, G.; Xian, J.; Gourlay, C.M. Al-Mn-Fe intermetallic formation in AZ91 magnesium alloys: Effects of impurity iron. Intermetallics 2022, 142, 110733. [CrossRef]

35. Gryguc, A.; Shaha, S.K.; Behravesh, S.B.; Jahed, H.; Wells, M.; Williams, B.; Su, X. Monotonic and cyclic behaviour of cast and cast-forged AZ80 Mg. Int. J. Fatigue 2017, 104, 136-149. [CrossRef]

36. Owen, E.; Pickup, L.; Roberts, I. Lattice constants of five elements possessing hexagonal structure. Z. Krist. Cryst. Mater. 1935, 91, 70-76. [CrossRef]

37. Thimmaiah, S.; Tener, Z.; Lamichhane, T.N.; Canfield, P.C.; Miller, G.J. Crystal structure, homogeneity range and electronic structure of rhombohedral $\gamma$-Mn5Al8. Z. Krist. Cryst. Mater. 2017, 232, 601-610. [CrossRef]

38. Kontio, A.; Stevens, E.; Coppens, P.; Brown, R.; Dwight, A.; Williams, J. New investigation of the structure of $\mathrm{Mn}_{4} \mathrm{Al}_{11}$. Acta Crystallogr. B Struct. Crystallogr. Cryst. Chem. 1980, 36, 435-436. [CrossRef]

39. Braun, P.B.; Goedkoop, J.A. An x-ray and neutron diffraction investigation of the magnetic phase $\mathrm{Al}_{0.89} \mathrm{Mn}_{1.11}$. Acta Crystallogr. 1963, 16, 737-740. [CrossRef]

40. Schobinger-Papamantellos, P.; Fischer, P. Neutronenbeugungsuntersuchung der Atomverteilung von $\mathrm{Mg}_{17} \mathrm{Al}_{12}$. Die Naturwissenschaften 1970, 57, 128-129. [CrossRef]

41. Ellner, M. The structure of the high-temperature phase $\mathrm{MnAl}(\mathrm{h})$ and the displacive transformation from $\mathrm{MnAl}_{(\mathrm{h})} \mathrm{into}_{\mathrm{Mn}} \mathrm{Al}_{8}$. Metall. Trans. A 1990, 21, 1669-1672. [CrossRef]

42. Sannes, S.; Westengen, H. The Influence of Process Conditions on the Microstructure and Mechanical Properties of Magnesium Die Castings. In Proceedings of the International conference and exhibition: Magnesium alloys and their applications, Wolfsburg, Germany, 28-30 April 1998; pp. 223-228.

43. Dahle, A.; Sannes, S.; John, D.S.; Westengen, H. Formation of defect bands in high pressure die cast magnesium alloys. J. Light Met. 2001, 1, 99-103. [CrossRef]

44. Fan, Z.; Liu, G.; Wang, Y. Microstructure and mechanical properties of rheo-diecast AZ91D magnesium alloy. J. Mater. Sci. 2006, 41, 3631-3644. [CrossRef]

45. Cao, H.; Wessén, M. Characteristics of microstructure and banded defects in die cast AM50 magnesium components. Int. J. Cast Met. Res. 2005, 18, 377-384. [CrossRef]

46. Cáceres, C.; Poole, W.; Bowles, A.; Davidson, C. Section thickness, macrohardness and yield strength in high-pressure diecast magnesium alloy AZ91. Mater. Sci. Eng. A 2005, 402, 269-277. [CrossRef]

47. Gourlay, C.; Laukli, H.; Dahle, A. Defect band characteristics in Mg-Al and Al-Si high-pressure die castings. Metall. Mater. Trans. A 2007, 38, 1833-1844. [CrossRef]

48. Li, X.; Yu, W.; Wang, J.; Xiong, S. Influence of melt flow in the gating system on microstructure and mechanical properties of high pressure die casting AZ91D magnesium alloy. Mater. Sci. Eng. A 2018, 736, 219-227. [CrossRef]

49. Bowles, A.; Nogita, K.; Dargusch, M.; Davidson, C.; Griffiths, J. Grain size measurements in Mg-Al high pressure die castings using electron back-scattered diffraction (EBSD). Mater. Trans. 2004, 45, 3114-3119. [CrossRef]

50. Yang, K.V.; Easton, M.A.; Caceres, C.H. The development of the skin in HPDC Mg-Al alloys. Mater. Sci. Eng. A 2013, 580, 191-195. [CrossRef]

51. Yu, W.; Cao, Y.; Li, X.; Guo, Z.; Xiong, S. Determination of interfacial heat transfer behavior at the metal/shot sleeve of high pressure die casting process of AZ91D alloy. J. Mater. Sci. Technol. 2017, 33, 52-58. [CrossRef]

52. Wang, L.; Nguyen, T.; Savage, G.; Davidson, C. Thermal and flow modelling of ladling and injection in high pressure die casting process. Int. J. Cast Met. Res. 2003, 16, 409-417. [CrossRef]

53. Li, X.-b.; Xiong, S.; Guo, Z.-p. On the porosity induced by externally solidified crystals in high-pressure die-cast of AM60B alloy and its effect on crack initiation and propagation. Mater. Sci. Eng. A 2015, 633, 35-41. [CrossRef]

54. Bi, C.; Xiong, S.; Li, X.; Guo, Z. Development of a fluid-particle model in simulating the motion of external solidified crystals and the evolution of defect bands in high-pressure die casting. Metall. Mater. Trans. B 2016, 47, 939-947. [CrossRef]

55. Li, X.-b.; Xiong, S.; Guo, Z.-p. Improved mechanical properties in vacuum-assist high-pressure die casting of AZ91D alloy. J. Mater. Process. Technol. 2016, 231, 1-7. [CrossRef] 
56. Zeng, G.; Zhu, X.; Ji, S.; Gourlay, C. The Morphology and Distribution of $\mathrm{Al}_{8} \mathrm{Mn}_{5}$ in High Pressure Die Cast AM50 and AZ91. In Magnesium Technology 2018, TMS 2018, Proceedings of the TMS Annual Meetings E Exhibition, Phoenix, AZ, USA, 11-15 March 2018; The Minerals, Metals \& Materials Series; Orlov, D., Joshi, V., Solanki, K., Neelameggham, N., Eds.; Springer: Cham, Switzerland, 2018; pp. 137-144.

57. Griffiths, W.; Lai, N.-W. Double oxide film defects in cast magnesium alloy. Metall. Mater. Trans. A 2007, 38, 190-196. [CrossRef]

58. Mirak, A.; Divandari, M.; Boutorabi, S.; Campbell, J. Oxide film characteristics of AZ91 magnesium alloy in casting conditions. Int. J. Cast Met. Res. 2007, 20, 215-220. [CrossRef]

59. Wang, L.; Rhee, H.; Felicelli, S.D.; Sabau, A.S.; Berry, J.T. Oxide Film and Porosity Defects in Magnesium Alloy AZ91. In Proceedings of the Shape Casting: 3rd International Symposium, San Francisco, CA, USA, 15-19 February 2009 ; p. 348.

60. Mirak, A.; Divandari, M.; Boutorabi, S.; Taylor, J. Effect of oxide film defects generated during mould filling on mechanical strength and reliability of magnesium alloy castings (AZ91). Int. J. Cast Met. Res. 2012, 25, 188-194. [CrossRef]

61. Li, T.; Davies, J.; Zhu, X. Effect of carrier gases on the entrainment defects within AZ91 alloy castings. J. Magnes. Alloy 2021. [CrossRef]

62. Campbell, J. Castings; Elsevier: Amsterdam, The Netherlands, 2003. 